
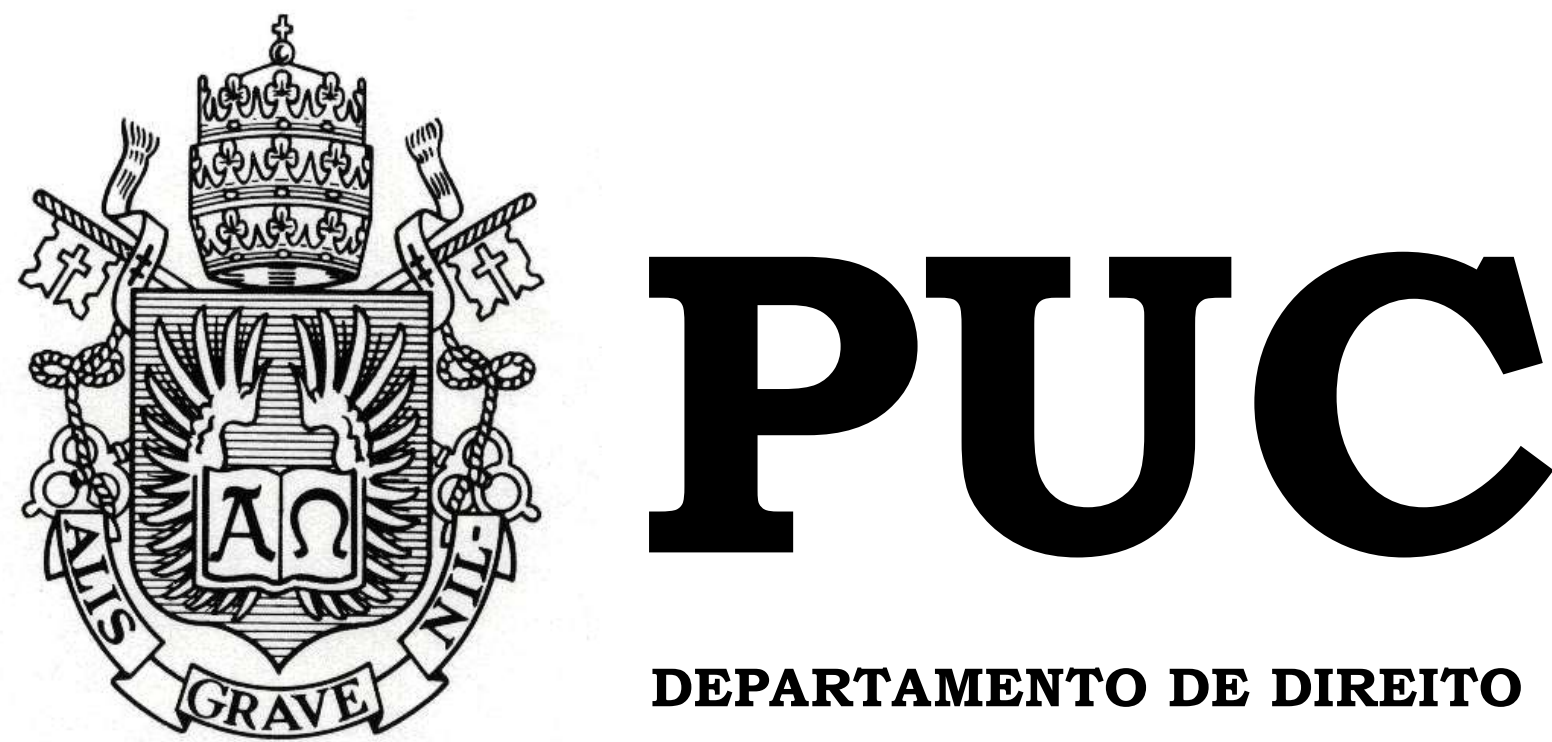

DEPARTAMENTO DE DIREITO

DA ADMINISTRAÇÃO E RESPONSABILIDADE DO ADMINISTRADOR DE SOCIEDADE LIMITADA À LUZ DA LEI DAS SOCIEDADES ANÔNIMAS

por

ALAIN RIBEIRO CROIX

ORIENTADORA: NORMA JONSSEN PARENTE

2016.2

PONTIFÍCIA UNIVERSIDADE CATÓLICA DO RIO DE JANEIRO RUA MARQUÊS DE SÃO VICENTE, 225 - CEP 22453-900 RIO DE JANEIRO - BRASIL 


\title{
DA ADMINISTRAÇÃO E RESPONSABILIDADE DO ADMINISTRADOR DE SOCIEDADE LIMITADA À LUZ DA LEI DAS SOCIEDADES ANÔNIMAS
}

\author{
por

\section{ALAIN RIBEIRO CROIX}

Monografia

apresentada

ao

Departamento de Direito da Pontificia Universidade Católica do Rio de Janeiro (PUC-Rio) para a obtenção do Título de Bacharel em Direito.

Orientador(a): Norma Jonssen Parente

2016.2 


\section{Resumo}

Croix, Alain Ribeiro. Da administração e responsabilidade do administrador de sociedade limitada à luz da lei das sociedades anônimas. 60p. Monografia (Graduação em Direito) - Pontifícia Universidade Católica do Rio de Janeiro: Rio de Janeiro, 2016.

A presente monografia tem por objetivo promover uma análise da administração das sociedades limitadas com base nas normas previstas na Lei de Sociedades Anônimas. Assim, em um primeiro momento será analisada brevemente a evolução histórica do direito comercial para se chegar ao conceito de direito empresarial e promover uma aproximação das sociedades limitadas e das sociedades anônimas por meio da aplicação supletiva da lei destas àquelas. Em seguida, serão abordadas as formalidades para formação da administração de uma sociedade limitada. Adicionalmente, verificar-se-á a aplicação nas sociedades limitadas dos deveres dos administradores previstos na Lei das Sociedades Anônimas. Por fim, este estudo proporá a análise da responsabilidade dos administradores face às obrigações constantes no Código Civil e na Lei das Sociedades Anônimas.

\section{Palavras Chave:}

Direito Empresarial - Sociedade Limitada - Sociedade Anônima Administrador - Responsabilidade Civil - Aplicação Supletiva - dever de diligência. 


\section{Sumário}

INTRODUÇÃO

CAPÍTULO 1 - DAS SOCIDADES EMPRESÁRIAS, UMA

APROXIMAÇÃO ENTRE AS SOCIEDADES LIMITADAS E

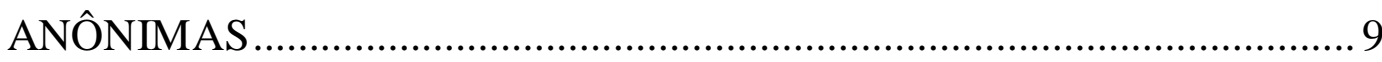

1.1. História do Direito Comercial - evolução mundial e influência

sobre o direito brasileiro ..................................................................... 9

1.1.1. As três fases históricas da evolução do direito comercial no

mundo

1.1.2. A quarta fase, o conceito de direito da empresa e a inspiração

italiana no ordenamento brasileiro

1.2. Conceito de empresário, o exercício de atividade empresarial em

sociedade e escolha do tipo societário da sociedade limitada.

1.3. Da possibilidade de optar pela aplicação supletiva da lei das

sociedades anônimas nas sociedades limitadas - limites. 166

\section{CAPÍTULO 2 - DA ADMINISTRAÇAO DAS SOCIEDADES}

LIMITADAS

2.1. Requisitos formais para o exercício da administração de sociedade

limitada 20

2.1.1. Conceituação da administração e impedimentos ............................... 20

2.1.2. Exercício do cargo por um ou mais administradores ...................... 22

2.1.3. Administração por sócio e não sócio .............................................. 22

2.1.4. Administração por pessoas físicas e jurídicas. ................................. 23

2.1.5. Administração por estrangeiros. ................................................. 25

2.1.6. Permanência e saída do administrador. ............................................ 27

2.1.7. Possibilidade de criação de um conselho de administração nas sociedades limitadas 
2.2. Normas de conduta no exercício da administração de sociedade limitada à luz dos deveres da Lei das Sociedades Anônimas..................... 31

2.2.1. O Dever de Diligência ................................................................. 32

2.2.1.1. O dever de se qualificar para o exercício da função.................... 344

2.2.1.2. O dever de bem administrar................................................... 355

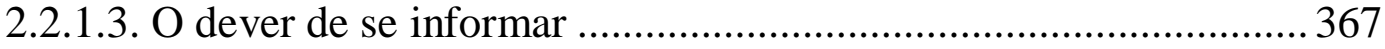

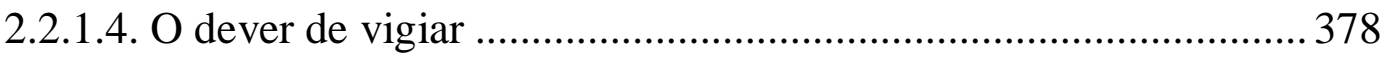

2.2.1.5. O dever de investigar ........................................................... 38

2.2.2. O Dever de Lealdade e sigilo ......................................................... 38

2.2.3. O Dever de Informação ................................................................ 40

2.2.4. O dever negativo de não se colocar em posição de conflito de interesses

CAPITULO 3 - DA RESPONSABILIDADE CIVIL DO

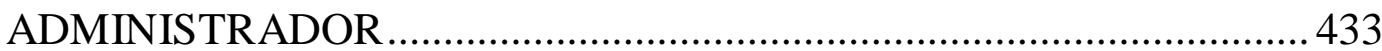

3.1. Responsabilidade Civil ............................................................ 433

3.1.1. Previsão no Código Civil............................................................. 43

3.1.2. Elementos da responsabilidade civil conforme a teoria subjetiva, confronto com a teoria objetiva. ....................................................... 44

3.2. Responsabilidade dos administradores .......................................... 45

3.2.1. Teoria Intra Vires e Ultra Vires ................................................. 488

3.2.2. Eficácia dos atos ultra vires....................................................... 49

3.2.3. Teoria da aparência.................................................................. 50

3.3. Responsabilidade do administrador em administração coletiva........... 52

3.4. Outros casos de responsabilidade do administrador.......................... 53

3.4.1. Omissão no uso da expressão "Limitada" ........................................ 53

3.4.2. Operações em desacordo com a maioria ...................................... 54

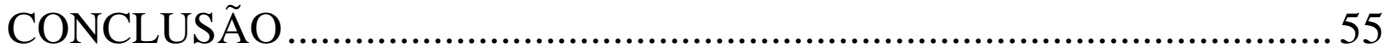

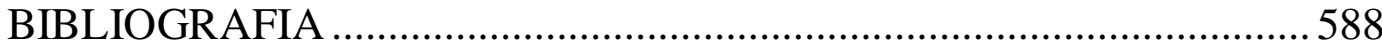




\section{INTRODUÇÃO}

A Constituição Federal de 1988 consagra, no seu artigo 170, o princípio da livre iniciativa ${ }^{1}$. É com base neste princípio que as pessoas se lançam nas mais diversas atividades econômicas com a finalidade de obter lucro.

Ocorre, contudo, que em todo empreendimento existe um risco inerente à atividade. Esse risco, se bem administrado, justifica a obtenção do lucro, mas também pode estar na raiz de grandes perdas.

É nessa tentativa de limitar o risco que as pessoas, os empresários, como serão tratados nesse estudo, se associam nas mais diversas estruturas jurídicas.

Criam-se, portanto, as sociedades. De forma objetiva e resumida, as sociedades podem representar associações de capital onde os investidores se mantêm ligados unicamente pela expectativa de lucro de determinada atividade, mas também associações de pessoas, conforme as características do intuitu personae, segundo o qual os sócios se associam em razão de uma ou mais características próprias a cada um deles. Enquanto na associação de capital, a forma de sociedade mais usual é a das sociedades anônimas, na associação de pessoas, a forma mais comum é a das sociedades limitadas. No entanto, segundo o pensamento de ABRÃO, embora diferentes no seu trato, ambas as formas têm em comum, a limitação da responsabilidade do sócio. ${ }^{2}$

1 Art. 170. A ordem econômica, fundada na valorização do trabalho humano e na livre iniciativa, tem por fim assegurar a todos existência digna, conforme os ditames da justiça social [...] (BRASIL. Constituição, 1988)

2 ABRÃO Nelson. Sociedades Limitadas. 10. ed. rev. atual e ampl. pelo Desembargador Carlos Henrique Abrão. São Paulo: Saraiva, 2012. p. 59 
Esse estudo tem especial interesse nesta segunda forma, a das sociedades limitadas. Embora não se possa negar que as sociedades anônimas sejam responsáveis pelas maiores movimentações do mercado brasileiro, é evidente que as sociedades limitadas, forma mais escolhida por pequenos e médios empresários, têm papel vital na nossa economia.

Assim, as sociedades limitadas têm, via de regra, uma estrutura mais dinâmica e menos burocrática que as sociedades anônimas. Não por acaso, muitas vezes são os próprios sócios que administram as sociedades limitadas.

Como já mencionado, um dos objetivos de constituir uma sociedade para explorar determinada atividade é justamente a obter a limitação de responsabilidade patrimonial. Nesse sentido, faz-se mister a aplicação da boa administração destas sociedades.

Assim, ainda que as sociedades limitadas estejam previstas e reguladas em nosso Código Civil (Lei n. 10.406, de 10 de janeiro de 2002), nosso legislador ofereceu a possibilidade, aos que quisessem, conforme o parágrafo único do artigo 1.053 do referido Código, de prever contratualmente a regência supletiva das normas das sociedades anônimas.

Ora, a Lei das Sociedades Anônimas (Lei n. 6.404, de 15 de dezembro de 1976) é um conjunto de normas especiais e modernas, que define a atuação das sociedades no mercado. A lei conforme explicitado na sua exposição de motivos, trata minuciosamente dos poderes, deveres e responsabilidade do administrador de forma a proteger os minoritários e assegurar a responsabilidade social do empresário ${ }^{3}$.

\footnotetext{
${ }^{3}$ Exposição de motivos n. 196, de 24 de junho de 1976, do Ministério da Fazenda.
} 
Por outro lado, o Código Civil, não trata do tema com tanta minúcia, de forma que é comum o operador do direito fazer uso das disposições da Lei das Sociedades Anônimas para pautar a atuação e a responsabilidade do administrador de sociedade limitada.

Nesse contexto, a presente monografia tem como objeto a análise da administração e responsabilidade do administrador de sociedade limitada à luz da Lei das Sociedades Anônimas.

O objetivo deste trabalho é estudar e compreender a boa administração das sociedades limitadas, com apoio nas regras previstas na Lei das Sociedades Anônimas e que podem ser aplicadas supletivamente nestas sociedades.

Busca-se, assim, de um lado, entender aspectos formais e substanciais para formação e atuação da administração de uma sociedade limitada e, do outro lado, verificar a responsabilidade dos administradores por atos praticados em nome da sociedade.

Para tanto, a monografia se divide em três capítulos.

O Capítulo 1 busca apresentar uma visão geral das sociedades empresárias, vez que este é o gênero em que se enquadram as sociedades limitadas. Assim, para uma melhor compreensão deste tipo societário no nosso ordenamento, faz-se importante uma breve análise da evolução histórica do Direito Comercial.

Da mesma forma, o estudo abordará o conceito de empresário, que é aquele que assume o risco da atividade e busca o lucro. O primeiro Capítulo se encerra aproximando as normas das sociedades limitadas com as das 
sociedades anônimas por meio da possibilidade de aplicação supletiva dessas àquelas regras.

O estudo evolui, em seu Capítulo 2, para uma análise das exigências formais e substanciais à administração das sociedades limitadas. São exigências formais aquelas previstas na lei que se referem às condições, requisitos e impedimentos à criação e funcionamento do órgão de administração da sociedade.

Assim, entender-se-á melhor quem pode ser o administrador e o modo de funcionamento desse órgão nas sociedades limitadas. Por outro lado, entende-se, para os fins deste trabalho, que são exigências substanciais, ou de conduta, as que definem e norteiam a atuação dos administradores. Nesta etapa serão abordadas as exigências substanciais previstas no Código Civil, mas, em especial, serão abordados os principais deveres dos administradores elencados na Lei das Sociedades Anônimas.

No Capítulo 3, será tratada a da responsabilidade civil dos administradores pelos atos praticados. Esse capítulo busca esclarecer em que medida os administradores serão ou não responsáveis por seus atos tanto nos termos do Código Civil como na Lei das Sociedades Anônimas, verificando quando se aplica uma lei ou outra. Para tanto, será necessário apresentar brevemente o instituto da responsabilidade civil que permitirá compreender as hipóteses de responsabilidade do Administrador.

O trabalho se encerra apresentando as considerações finais na qual será feita uma breve síntese dos argumentos propostos durante esse estudo. 


\section{CAPÍTULO 1 - DAS SOCIDADES EMPRESÁRIAS, UMA APROXIMAÇÃO ENTRE AS SOCIEDADES LIMITADAS E ANÔNIMAS}

\subsection{História do Direito Comercial - evolução mundial e influência sobre o direito brasileiro}

\subsubsection{As três fases históricas da evolução do direito comercial no mundo}

Embora se tenha registro de atividades de associações comerciais já no Direito Romano ${ }^{4}$, a noção de limitação de responsabilidade, com a separação entre o patrimônio da sociedade e o dos sócios só surgiu no início do século XII com as companhias de comércio. Curioso notar, segundo $\mathrm{BORBA}^{5}$ que estas companhias adotaram uma forma jurídica similar às da sociedade por ações que conhecemos hoje.

De acordo com NEGRÃO, encontramo-nos atualmente na quarta fase de evolução do Direito Comercial (que passa a ser conhecida como Direito de Empresa). Assim, são três as fases históricas que ajudam a compreender a origem do nosso Direito Comercial, são elas: (i) as de mercados e trocas (séculos XII a XVI); (ii) a do mercantilismo e colonização (séculos XVII e XVIII); e (iii) a do liberalismo econômico (Século XIX).

\footnotetext{
${ }^{4}$ É o que afirma BORBA: "Os primeiros documentos legislativos conhecidos, nos quais já se vislumbra a origem do direito societário, situam-se, contudo, no Direito Romano. [...] Posteriormente ocorreriam as sociedades de publicanos, as quais tinham por escopo explorar atividades ligadas ao Poder Público, inclusive o recolhimento de rendas do Estado." (BORBA, José Edwaldo Tavares. Direito societário. 13.ed. rev. e atual. Rio de Janeiro: Renovar, 2012. p. 2.) ${ }^{5}$ BORBA, José Edwaldo Tavares. Direito societário. 13.ed. rev. e atual. Rio de Janeiro: Renovar, 2012. p. 2.
} 
Não se pretende aqui aprofundar ou exaurir o tema, mas apenas traçar um breve comentário sobre estas fases para melhor entender a existência das sociedades limitadas e anônimas no ordenamento brasileiro.

Assim, a primeira fase da história do Direito Comercial se inicia justamente no início do século XII e se estende até o século XVI ${ }^{6}$. Esta fase é sobretudo marcada pela ascensão política, econômica e social das corporações. Classes de mercadores que se reuniam para patrocinar feiras, elaborar regulamentos, dirimir conflitos, garantir a segurança das campanhas. Trata-se de um verdadeiro direito do comerciante.

Nesta fase, é criado o comércio itinerante onde as companhias viajavam para oferecer seus mais variados produtos nas diferentes cidades, em feiras, parecidas com as de hoje. As feiras, sazonais, rapidamente evoluem para mercados especializados e surgem as lojas de vendas constantes dos mesmos produtos ${ }^{7}$.

Se hoje as atividades acima citadas estão bastante popularizadas, de forma que são exercidas por pequenos empresários e empresas, nesta época eram altamente elitizadas e caras. Seu alto custo, inclusive, fomentou a criação de diversos instrumentos até hoje utilizados como, por exemplo: “o câmbio, os títulos de crédito, os bancos e, sobretudo as bolsas, famosos lugares de encontro de banqueiros, mercadores, cambistas, negociantes, corretores", contratos de seguros, entre outros.

A segunda fase da evolução do Direito Comercial coincide com o mercantilismo e a expansão das colonizações (séculos XVII e XVIII) e fica caracterizado por uma grande positivação do Direito Comercial e Marítimo.

\footnotetext{
${ }^{6}$ NEGRÃO, Ricardo. Manual de direito comercial e de empresa, volume 1: teoria geral da empresa e direito societário. 12. ed. São Paulo: Saraiva, 2015. p. 26.

7 Ibid. p. 28-29.

${ }^{8}$ Ibid. p. 29.
} 
De acordo com ALVES, “as associações são lícitas, desde que o Rei as autorize" 9 . Denota-se grande ingerência do poder público nas expedições, ao mesmo tempo que este as patrocina.

A terceira fase ocorre com o surgimento do conceito de liberalismo econômico do século XIX, sobretudo com a edição do Código Civil de Napoleão em 1806 na França.

Afasta-se do conceito de direito do comerciante para chegar em um direito do comércio, ou dos atos do comércio. Assim, passa-se a abranger com a lei específica todos aqueles que praticam atos do comércio com habitualidade e com profissionalismo. Nesse sentido, segundo COELHO:

A elaboração doutrinária fundamental do sistema francês é a teoria dos atos de comércio, vista como instrumento de objetivação do tratamento jurídico da atividade mercantil. Isto é, com ela, o direito comercial deixou de ser apenas o direito de uma certa categoria de profissionais, organizados em corporações próprias, para se tornar a disciplina de um conjunto de atos que, em princípio, poderiam ser praticados por qualquer cidadão ${ }^{10}$.

É nesta fase, na Alemanha, que nascem as primeiras sociedades $\operatorname{limitadas}^{11}$. De fato, as sociedades consideradas civis passam a ser acolhidas sob o mesmo teto legal daquelas consideradas propriamente comerciais.

\subsubsection{A quarta fase, o conceito de direito da empresa e a inspiração italiana no ordenamento brasileiro}

Hoje vive-se a quarta fase descrita por NEGRÃO. Esta representa a progressão do conceito de direito do comércio para o direito de empresa, movimento este que deve em muito ao pensamento italiano.

\footnotetext{
${ }^{9}$ ALVES, Alexandre Ferreira de Assumpção. A Pessoa Jurídica e os Direitos da Personalidade. Rio de Janeiro: Renovar, 1998. p.25

${ }^{10}$ COELHO, Fábio Ulhoa. Curso de direito comercial, volume 1. 9. ed., rev. e atual. São Paulo: Saraiva, 2005. p. 12

${ }^{11}$ BORBA, José Edwaldo Tavares. Direito societário. 13.ed. rev. e atual. Rio de Janeiro: Renovar, 2012. p. 3.
} 
O modelo de Direito Comercial Italiano ou, em conformidade com a nova denominação adotada, de Empresa, na definição de COELHO, "é o estabelecimento de um regime geral de disciplina privada da atividade econômica, que apenas não alcança certas modalidades de importância marginal" 12 .

Nesse sentido, o nosso Código Civil vigente adota expressamente o conceito de teoria da empresa e define o conceito de empresário, como será tratado adiante no item 1.1.3. infra.

Esse estudo pretende analisar a administração e a responsabilidade do administrador de sociedade limitada à luz das regras próprias de sociedade anônima. Para tanto, mostrou-se uma breve evolução mundial do Direito Comercial, que em um primeiro momento era feito pelas corporações para os comerciantes, e onde prevaleciam as estruturas capitalísticas próprias das sociedades anônimas. Em seguida, o Direito Comercial, ou dos comerciantes, evoluiu para um direito dos atos do comércio, quando surgiram as primeiras sociedades limitadas. Por fim, com a influência do pensamento italiano, procurou-se unir os atos civis e os comerciais propriamente ditos em um Direito da Empresa.

Procura-se, por meio dessa análise jurídica e histórica, aproximar as espécies societárias da sociedade limitada e da sociedade anônima e entender de que forma é justificável incorporar normas desta na esfera daquela.

Assim, ao encontro desta proposta, tem-se a seguinte declaração de ABRÃO, sobre o Código Civil vigente: ${ }^{12}$ COELHO, Fábio Ulhoa. Curso de direito comercial, volume 1. 9. ed., rev. e atual. São Paulo:
Saraiva, 2005. p. 22 
Mostra-se muito evidente a diretriz de procurar dotar o tipo societário de estrutura e consistente funcionamento semelhantes aos das companhias (sociedades anônimas), pela divisão do capital em quotas e limitação de responsabilidade ao seu montante; maior flexibilização na cessão das quotas a terceiros; administração por uma ou mais pessoas, sócias ou não; existência de conselho fiscal e assembleia, essa última para fins expressamente disciplinados (arts. 1.072 e seguintes do $\mathrm{CC})^{13}$

\subsection{Conceito de empresário, o exercício de atividade empresarial em sociedade e escolha do tipo societário da sociedade limitada.}

Conforme mencionado, nosso Código Civil adota a teoria da empresa e define a noção de empresário. Esta definição encontra-se em seu artigo 966, o primeiro do Capítulo I, do Título I, do Livro II chamado Do Direito de Empresa, veja-se abaixo:

Art. 966. Considera-se empresário quem exerce profissionalmente atividade econômica organizada para a produção ou a circulação de bens ou de serviços.

Parágrafo único. Não se considera empresário quem exerce profissão intelectual, de natureza científica, literária ou artística, ainda com o concurso de auxiliares ou colaboradores, salvo se o exercício da profissão constituir elemento de empresa.

Interessante notar que nosso ordenamento optou por não definir o conceito de empresa, mas de empresário. Nesse sentido é empresário aquele que exerce profissionalmente atividade econômica organizada para a produção ou circulação de bens e serviços.

Nota-se, portanto, que não basta ter uma sociedade plenamente constituída em acordo com as normas legais para caracteriza-la de empresária, é preciso que o empresário faça transparecer o elemento de empresa para tanto. Nesse sentido, entende CAMPINHO: "nasce a empresa a partir do início da atividade economicamente organizada, sob o comando do empresário"14.

\footnotetext{
${ }^{13}$ ABRÃO Nelson. Sociedades Limitadas. 10. ed. rev. atual e ampl. pelo Desembargador Carlos Henrique Abrão. São Paulo: Saraiva, 2012. p. 46

${ }^{14}$ CAMPINHO, Sergio. O direito de empresa à luz do novo código civil. 6. Edição revista e atualizada conforme a lei 11.101/2005. Rio de Janeiro: Renovar, 2005. p.11.
} 


\begin{abstract}
Abandona-se, portanto, a teoria dos atos de comércio para adotar uma teoria muito mais abrangente, que mistura os atos civis e os comerciais, de forma que podem ser considerados empresários, estando assim protegidos pela legislação pertinente, todos àqueles que fizerem transparecer o elemento de empresa.
\end{abstract}

Com relação aos que exercem profissão intelectual, de natureza científica, literária ou artística, ainda com o concurso de auxiliares ou colaboradores. Importante notar que o legislador voluntariamente os excluiu da condição de empresários, muito embora estas atividades tenham valor econômico. Até mesmo estas profissões, quando revestidas do elemento de empresa, têm garantida a condição de empresário. ${ }^{15}$

O empresário, enquadrado na definição acima mencionada, ao decidir explorar sua atividade econômica em sociedade, deve revestir-se de um dos tipos prescritos em lei. Não cabe nesse estudo analisar os diversos tipos societários possíveis, bastando, para a finalidade aqui pretendida, elencar as hipóteses. São elas: sociedade em nome coletivo; sociedade em comandita simples; sociedade limitada; sociedade em comandita por ações ${ }^{16}$. Por força de lei, as sociedades anônimas sempre serão consideradas empresárias, independentemente de seu objeto ${ }^{17}$.

Conforme já mencionado, o tipo societário da sociedade limitada é mais frequentemente adotado pelos empresários do que os demais. Razão pela qual se escolheu não desenvolver os demais tipos.

\footnotetext{
${ }^{15}$ CAMPINHO, Sergio. O direito de empresa à luz do novo código civil. 6. Edição revista e atualizada conforme a lei 11.101/2005. Rio de Janeiro: Renovar, 2005. p.14.

${ }^{16}$ BRASIL, Código Civil, art. 983

${ }^{17}$ BRASIL, Código Civil, art. 983, parágrafo único.
} 
Dentre os efeitos da aquisição da condição de empresária pela Sociedade, podemos citar, por exemplo, a obrigação de registro perante o Registro Público de Empresas Mercantis ${ }^{18}$ e, mais precisamente, o Departamento de Registro Empresarial e Integração (DREI) e suas juntas comerciais. Assim, para que uma sociedade empresária esteja regularmente constituída é necessário cumprir com a condição acima.

No entanto, salvo algumas exceções, um relevante efeito da obtenção da condição de empresário é a possibilidade de requerer a recuperação judicial e a falência nos termos da lei 11.101/2005 ${ }^{19}$.

Nota-se, então, que tanto as sociedades anônimas quanto as sociedades limitadas são sociedades empresárias protegidas pelo Direito de Empresa, ainda que as sociedades anônimas sejam reguladas por lei especial, a lei 6.404 de 15 de dezembro de 1976.

Nesse sentido, passa-se à análise da medida em que as sociedades limitadas também podem ser regidas pelas regras especiais às sociedades anônimas.

\footnotetext{
${ }^{18}$ BRASIL, Código Civil, art. 967

${ }^{19}$ A lei 11.101/2005 se aplica a sociedades empresárias, no entanto, conforme se pode notar a seguir, não se aplica à empresa pública e sociedade de economia mista nem a instituição financeira pública ou privada, cooperativa de crédito, consórcio, entidade de previdência complementar, sociedade operadora de plano de assistência à saúde, sociedade seguradora, sociedade de capitalização e outras entidades legalmente equiparadas às anteriores "Art. 1o Esta Lei disciplina a recuperação judicial, a recuperação extrajudicial e a falência do empresário e da sociedade empresária, doravante referidos simplesmente como devedor. Art. 2o Esta Lei não se aplica a: I empresa pública e sociedade de economia mista; II - instituição financeira pública ou privada, cooperativa de crédito, consórcio, entidade de previdência complementar, sociedade operadora de plano de assistência à saúde, sociedade seguradora, sociedade de capitalização e outras entidades legalmente equiparadas às anteriores."
} 


\title{
1.3. Da possibilidade de optar pela aplicação supletiva da lei das sociedades anônimas nas sociedades limitadas - limites.
}

O Código Civil prevê, no parágrafo único do artigo 1.053 que o contrato social de sociedade limitada poderá prever a regência supletiva da lei especial das sociedades anônimas.

A primeira observação que se pode fazer sobre o tema, é que a regência supletiva depende da vontade das partes. Este detalhe não deve passar despercebido, uma vez que a própria lei dá tratamento diverso à regência das regras das sociedades simples. Enquanto esta é cogente, isto é, aplica-se à revelia de vontade das partes, aquela é dispositiva, ou seja, depende de acordo dos sócios para valer.

Outra importante observação se refere à forma de aplicação "supletiva" escolhida pelo legislador. Não se deve confundir a aplicação supletiva com a aplicação subsidiária. Para tanto, transcreve-se o ensinamento de BORBA:

\begin{abstract}
Atente-se, porém, para as limitações dessa regência supletiva. Aplicação supletiva não se confunde com aplicação subsidiária. Sendo supletiva, destina-se a suprir as omissões do contrato, incidindo naquelas hipóteses a respeito das quais poderia dispor o contrato. Ademais, cabe acentuar que a aplicação subsidiária significa a integração da legislação subsidiária na legislação principal, de modo a preencher os claros desse complexo normativo, com preceitos imperativos e dispositivos. ${ }^{20}$
\end{abstract}

Assim, tem-se que a Lei das Sociedades Anônimas somente se aplica às sociedades limitadas naquilo sobre o que as partes poderiam dispor, sobre as normas dispositivas.

Ainda segundo os ensinamentos de BORBA, ainda que os sócios tenham decidido pela aplicação da Lei das Sociedades Anônimas, as regras

\footnotetext{
${ }^{20}$ BORBA, José Edwaldo Tavares. Direito societário. 13.ed. rev. e atual. Rio de Janeiro: Renovar, 2012. p. 128.
} 
das sociedades limitadas e das sociedades simples continuarão a valer em tudo aquilo que for próprio às sociedades limitadas, incompatíveis com as sociedades anônimas, enfim, sempre que se tratar de norma imperativa.

Assim, ainda que o contrato social seja expresso no sentido de optar pela aplicação supletiva da Lei das Sociedades Anônimas, se as partes não pudessem dispor sobre a matéria, esta não poderia ser aplicada. COELHO corrobora o entendimento acima, introduzindo a noção de contratualidade:

A contratualidade da matéria - isto é, a possibilidade de os sócios a regularem por manifestação de vontade - é pressuposto para a invocação da lei do anonimato como supletiva da disciplina específica das limitadas constantes do Código Civil. Se o tema não é tratado no contrato social - e não poderia ser tratado no contrato social - então a legislação das sociedades anônimas é inaplicável às limitadas. ${ }^{21}$

A fim de ilustrar essa importante questão, indaga-se acerca da possibilidade de criação de quotas preferenciais para as sociedades limitadas que tenham optado pela aplicação supletiva da Lei das Sociedades Anônimas.

Ora, a Lei das Sociedades Anônimas prevê no parágrafo primeiro do artigo 11 que a companhia que possuir ações sem valor nominal, poderá prever a criação de "uma ou mais classes de ações preferenciais com valor nominal".

A mesma possibilidade, contudo, não se estende às sociedades limitadas. Isto se verifica no item 1.2.16.3 do Manual de Registro de Sociedade Limitada aprovado pela Instrução Normativa n. 10, de 05 de dezembro de 2013 do Departamento de Registro Empresarial e

\footnotetext{
${ }^{21}$ COELHO, Fábio Ulhoa. Curso de direito comercial, volume 2: direito de empresa. 11. ed., rev. e atual. São Paulo: Saraiva, 2008. p. 367-368.
} 
Integração22, bem como no Informativo da Junta Comercial do Estado do Rio de Janeiro n. 64 de outubro de 201323

Conforme demonstrado acima, a extensão da aplicação subsidiária da norma especial ainda causa certa incerteza aos aplicadores. Assim, concluise o presente tema com uma crítica já formulada por ABRÃO, transcrita abaixo:

O ideal em matéria de regulação de sociedade por quotas de responsabilidade limitada seria uma disciplina completa do instituto, a exemplo, aliais, do que ocorre com os demais tipos societários, sem se deixarem lacunas para aplicações legais subsidiárias, a não ser, quando for o caso, dos princípios gerais que regem a sociedade como contrato. ${ }^{24}$

A preocupação da doutrina com o tema não é nova, TEIXEIRA já demonstrava a mesma inquietação antes mesma da promulgação do novo Código Civil, criticando as disposições legais então vigentes que assim, como as de hoje, não tranquilizavam os operadores do direito:

É trabalho ingente do intérprete e do aplicador da lei definir, em cada caso concreto, se a norma supletiva da sociedade anônima se ajusta à índole e à estrutura da sociedade limitada em foco [...]. Daí a possibilidade de opiniões divergentes e de acórdãos conflitantes até que a lei das sociedades limitadas seja promulgada pelo Congresso Nacional. É que o que desejamos que aconteça para a tranquilidade de advogados, partes, juristas e magistrados. ${ }^{25}$

O tema da presente monografia, torna-se ainda mais relevante considerando as críticas dos doutrinadores acima citados, bem como de inúmeros operadores do Direito. Deste modo, caso houvesse legislação e princípios próprios, específicos e hermenêuticos, não haveria que se estudar a administração e responsabilidade do administrador de sociedade limitada à luz da Lei de Sociedades Anônimas, salvo à título comparativo. Ora, não é o que se pretende com este estudo.

\footnotetext{
${ }^{22}$ 1.2.16.3 - Quota preferencial - Não cabe para sociedade limitada a figura da quota preferencial.

${ }^{23}$ Não cabe para sociedade limitada a figura da quota preferencial.

${ }^{24}$ ABRÃO Nelson. Sociedades Limitadas. 10. ed. rev. atual e ampl. pelo Desembargador Carlos Henrique Abrão. São Paulo: Saraiva, 2012. p. 51 e 52.

${ }^{25}$ TEIXEIRA Egberto Lacerda. Sociedades limitadas e anônimas no direito brasileiro: estudo comparativo. São Paulo: Saraiva, 1987. p. 82
} 
Busca-se aqui, identificar uma verdadeira linha de orientação na condução da administração de sociedade limitada, pautada nos dispositivos especiais da Lei das Sociedades Anônimas, eventualmente confrontando-os com os já existentes no Código Civil.

Assim, nos próximo Capítulo serão apresentados os requisitos materiais e substanciais para o bom exercício da administração de uma sociedade limitada, pautando a atuação do administrador, sempre que possível nas orientadas fixadas na Lei das Sociedades Anônimas. 


\section{CAPÍTULO 2 - DA ADMINISTRAÇAO DAS SOCIEDADES LIMITADAS}

\subsection{Requisitos formais para o exercício da administração de sociedade limitada}

Conforme já mencionado, a aplicação da Lei das Sociedades Anônimas só é possível nas sociedades limitadas, ainda que com manifestação de vontade dos sócios, naquilo em que as partes puderem pactuar. Ora, os requisitos formais necessários ao exercício da administração não são estipuláveis entre os sócios, que se submetem inteiramente às disposições do Código Civil. Ainda assim, é possível extrair das normas das sociedades anônimas normas que podem ser compreendidas como norte para a atuação dos administradores das sociedades limitadas, de forma que podem ser compreendidas como auxiliares dos requisitos formais a seguir tratados.

\subsubsection{Conceituação da administração e impedimentos}

A administração é o órgão de representação das sociedades limitadas. É por meio deste órgão que as sociedades limitadas vão interagir com terceiros a fim de cumprir sua finalidade social. Nesse sentido, em nada dispondo o contrato, os administradores possuem todos os poderes para praticar todos os atos pertinentes à gestão da sociedade ${ }^{26}$, sendo certo que o uso da firma ou denominação da sociedade limitada é de uso privativo da administração ${ }^{27}$.

\footnotetext{
${ }^{26}$ BRASIL. Código Civil, art. 1.015.

${ }^{27}$ BRASIL. Código Civil, art. 1.064.
} 
Importante destacar que a administração não é meramente uma delegação, um mandato, como se questionava no Código Civil de $1916^{28}$. Dispõe evidentemente de uma natureza de organicidade, os poderes de gestão dos administradores são indelegáveis. Sobre o assunto, ABRÃO afirma:

Prevalece hoje a doutrina da organicidade, segundo a qual os administradores não são apenas meros mandatários da sociedade, ou dos sócios, porém manifestantes da própria vontade daquela, fazendo-a presente. ${ }^{29}$

Por fim, importante frisar que não basta ter a plena capacidade civil para exercer o cargo de administrador, é preciso respeitar os requisitos negativos. Nesse sentido, o Código Civil tratou de elencar, de forma taxativa, todos os casos de impedimento ao exercício do mandato. Note-se ainda que os casos de impedimento do administrador de sociedade limitada são ainda mais extensos do que aqueles previstos para os diretores de sociedade anônima ${ }^{30}$. Assim, pela redação do parágrafo único do artigo 1.011 do Código Civil,

Não podem ser administradores, além das pessoas impedidas por lei especial, os condenados à pena que vede, ainda que temporariamente, o acesso a cargos públicos; ou por crime falimentar, de prevaricação, peita ou suborno, concussão, peculato; ou contra a economia popular, contra o sistema financeiro nacional, contra as normas de defesa da concorrência, contra as relações de consumo, a fé pública ou a propriedade, enquanto perdurarem os efeitos da condenação.

\footnotetext{
${ }^{28}$ Sobre o tema discorre TEIXEIRA: "mercê da força de interpretação construtiva, a doutrina e a prática sancionada pelo Registro do Comércio têm aceito a nomeação de gerentes não sócios através do mecanismo jurídico da delegação de poderes prevista no art. 13 do Decreto 3.708/19, verbis:

É lícito aos gerentes delegar o uso de firma somente quando o contrato não contiver cláusula que se oponha a essa delegação. Tal delegação, contra disposição do contrato, dá ao sócio que a fizer, pessoalmente, a responsabilidade das obrigações contraídas pelo substituto, sem que possa reclamar da sociedade mais do que a sua parte das vantagens auferidas do negócio. (TEIXEIRA Egberto Lacerda. Sociedades limitadas e anônimas no direito brasileiro: estudo comparativo. São Paulo: Saraiva, 1987. p. 10)

${ }^{29}$ ABRÃO Nelson. Sociedades Limitadas. 10. ed. rev. atual e ampl. pelo Desembargador Carlos Henrique Abrão. São Paulo: Saraiva, 2012. p. 153.

${ }^{30}$ Art. 147, §10 (lei 6.404/76): São inelegíveis para os cargos de administração da companhia as pessoas impedidas por lei especial, ou condenadas por crime falimentar, de prevaricação, peita ou suborno, concussão, peculato, contra a economia popular, a fé pública ou a propriedade, ou a pena criminal que vede, ainda que temporariamente, o acesso a cargos públicos.
} 


\subsubsection{Exercício do cargo por um ou mais administradores}

Dispõe o Código Civil, que a sociedade limitada poderá ser administrada por uma ou mais pessoas designadas no contrato social ou em ato separado ${ }^{31}$. Destarte, vê-se que, ao contrário das sociedades anônimas, onde a diretoria, órgão de administração das companhias, é formada por ao menos dois diretores, ${ }^{32}$ na sociedade limitada basta um administrador.

Havendo mais de um administrador e em sendo omisso o contrato social, a administração competirá obrigatoriamente separadamente à cada $\mathrm{um}^{33}$, por força da aplicação subsidiária cogente das normas das sociedades simples.

\subsubsection{Administração por sócio e não sócio}

Não é necessário ser sócio para exercer o cargo de administrador das sociedades limitadas. Os administradores não sócios, bem como os administradores sócios, podem ser indicados no próprio contrato ou em ato apartado.

Importante notar que a nomeação de administradores não sócios depende de aprovação unânime dos sócios enquanto o capital não estiver integralizado e de ao menos dois terços após integralização ${ }^{34}$. Ocorre que a lei não esclarece se os dois terços se referem ao número de sócios ou ao capital social. Assim, segue-se o entendimento de BORBA acerca do assunto: “[..] considerando que o princípio prevalecente na lei é o da

\footnotetext{
${ }^{31}$ Brasil, Código Civil, art. 1.060

${ }^{32}$ Brasil, lei n. 6.404 de 15 de dezembro de 1976, art. 143.

${ }^{33}$ Brasil, Código Civil, art. 1.013, parágrafo primeiro.

${ }^{34}$ Brasil, Código Civil, art. 1.061
} 
maioria do capital, daí se segue a conclusão lógico-dedutiva de que os dois terços concernem ao capital"’35.

A escolha da forma de indicação dos administradores, terá especial relevância no momento de sua destituição, assunto que será tratado adiante no item 2.1.6., abaixo. De toda forma, o administrador nomeado em ato apartado do contrato social toma posse mediante assinatura de termo que deve ser averbado nos livros de atas da administração, o que deve ser feito nos trinta dias subsequentes à sua nomeação, sob pena de nulidade do ato ${ }^{36}$. Ressalta-se ainda que o termo de posse deve ser levado ao registro competente.

No mais, é possível que a administração seja atribuída a todos os sócios no contrato social. Sobre este fato, importante ressaltar que os sócios posteriores que ingressarem na sociedade não terão esta prerrogativa estendida de pleno direito, é o que diz o parágrafo único do artigo 1.060 do Código Civil. BORBA esclarece: “os futuros sócios só terão poderes de administração se receberem uma outorga específica, ou se houver uma renovação da atribuição da administração a todos os sócios"37.

\subsubsection{Administração por pessoas físicas e jurídicas.}

A possibilidade de administração das sociedades limitadas por pessoas físicas ou jurídicas é um tema que suscitou discussão na doutrina, embora hoje já esteja definido pelo órgão de Registro Público de Empresas Mercantis que vetou esta hipótese.

\footnotetext{
${ }^{35}$ BORBA, José Edwaldo Tavares. Direito societário. 13.ed. rev. e atual. Rio de Janeiro: Renovar, 2012. p. 132.

${ }^{36}$ Brasil, Código Civil, art. 1.062 e parágrafo primeiro.

${ }^{37}$ BORBA, José Edwaldo Tavares. Op.cit.
} 
A norma que trata do assunto é imprecisa e diz somente que a sociedade limitada poderá ser administrada por uma ou mais pessoas. Notese que não especifica se estas pessoas poderão ser pessoas naturais ou jurídicas.

Deste modo, de um lado, temos a declaração de BORBA que entende ser possível a administração por pessoa jurídica, vez que a lei não limitou o tema. In verbis:

Esses administradores poderão ser pessoas naturais ou pessoas jurídicas, uma vez que, onde o legislador não distinguiu (art. 1.060, que se refere a "uma ou mais pessoas", indistintamente), não cabe ao intérprete distinguir. Quando o legislador quis distinguir, como o fez em relação à sociedade simples, fê-lo expressamente (art. 997, VI), para tornar a administração privativa de pessoas naturais ${ }^{38}$.

Por outro lado, ABRÃO advoga no sentido de que apenas pessoas físicas poderiam exercer a administração de sociedade limitada. $\mathrm{O}$ faz argumentando que a administração tem caráter eminentemente pessoal, imediato e diretivo ${ }^{39}$. Não por acaso, o poder de gestão dos administradores não pode ser delegado.

Já CAMPINHO, embora seja da mesma opinião de ABRÃO no que se refere à apenas pessoas físicas serem capazes de exercer cargo de administrador de sociedades limitadas, defende o argumento com base na aplicação subsidiária das normas relativas às sociedades simples.

Ora, o Código Civil expressamente prevê aplicação subsidiária das normas das sociedades simples nas omissões do Capítulo destinado às sociedades limitadas ${ }^{40}$.

Ao contrário da aplicação das normas referentes à Lei das Sociedades Anônimas, que é apenas supletiva e depende de manifestação

\footnotetext{
${ }^{38}$ BORBA, José Edwaldo Tavares. Direito societário. 13.ed. rev. e atual. Rio de Janeiro: Renovar, 2012. p. 131.

${ }^{39}$ ABRÃO Nelson. Sociedades Limitadas. 10. ed. rev. atual e ampl. pelo Desembargador Carlos Henrique Abrão. São Paulo: Saraiva, 2012. p. 158.

${ }^{40}$ Brasil. Código Civil, artigo, 1.053
} 
expressa de vontade dos sócios, as normas das sociedades simples se aplicam por força de ordem legal. Nesse sentido ainda segundo CAMPINHO, "conforme se extrai do artigo 997, VI, de aplicação à limitada por força do artigo 1.054, a administração fica restrita à pessoa natural, a qual pode ser estranha ao corpo social".

Destaca-se ainda que o próprio o item 1.2.23.4 do Manual de Registro de Sociedade Limitada aprovado pela Instrução Normativa n. 10, de 05 de dezembro de 2013 do Departamento de Registro Empresarial e Integração esclarece que a pessoa jurídica não pode ser administradora ${ }^{41}$.

Conclui-se fazendo uma crítica à norma, vez que toda discussão somente existe em razão de imprecisão na diretriz. Ainda que se utilize do raciocínio lógico-dedutivo de aplicar as disposições referentes às sociedades anônimas, seria mais pacificador para todos os operadores do direito que nosso legislador tivesse tido mais zelo na redação do dispositivo.

\subsubsection{Administração por estrangeiros.}

O Código Civil é omisso quanto a possibilidade de o administrador ser estrangeiro ou não residente. No entanto, este tema é pacífico na doutrina e na jurisprudência no sentido de que estrangeiros podem exercer a administração de sociedade limitada na condição de serem residentes nos país. Assim elucida ABRÃO: “inexiste óbice legal destacado pelo Código Civil em vigor no que respeita à designação de administrador estrangeiro; caberia, porém, monitorar melhor a indicação e assegurar um mínimo de recurso patrimonial em razão do mercado e condições do negócio" 42 .

\footnotetext{
${ }^{41}$ 1.2.23.4 - Administrador - pessoa jurídica A pessoa jurídica não pode ser administradora.

42 ABRÃO Nelson. Sociedades Limitadas. 10. ed. rev. atual e ampl. pelo Desembargador Carlos Henrique Abrão. São Paulo: Saraiva, 2012. p. 164.
} 
Mais uma vez, a omissão das disposições do Código Civil leva os que tratam das sociedades limitadas a buscarem informações e nortes nas disposiçõos das sociedades anônimas. Assim, tem-se que, de acordo com o artigo 146 da lei 6.404 de 15 de dezembro de 1976, que "poderão ser eleitas para membros dos órgãos de administração pessoas naturais, devendo os diretores ser residentes no País".

Observa-se que a lei prescreve apenas que o estrangeiro deva ser residente no Brasil e não domiciliado. Na prática, ao contrário, o que se verifica é uma inversão da regra: exige-se do estrangeiro, para que possa administrar uma sociedade anônima que tenha domicilio no Brasil. Destacase a lição de GOMES que esclarece a distinção entre residente e domicilio:

Se a noção de domicilio fosse indissoluvelmente ligada ao fato de residir, como pensam alguns, domicilio e residência não se distinguiria. Mas, em verdade, o que importa fundamentalmente na caracterização do domicílio é a determinação do lugar onde a pessoa exerce sua profissão ou tem suas ocupações habituais. Pode ocorrer que alguém resida num lugar e exerça em outro a atividade econômica ou profissional. ${ }^{43}$

Ora, atualmente, para que um estrangeiro possa exercer cargo de administração de sociedade limitada ou ainda de sociedade anônima, é necessário apresentar o registro de residência permanente. Em outras palavras, perante a lei brasileira, para que um estrangeiro ocupe cargo em órgão de administração de sociedade, é necessário que ele venha ao Brasil com animus definitivo ${ }^{44}$.

\footnotetext{
${ }^{43}$ GOMES, Orlando. Introdução ao direito civil. Revista, atualizada e aumentada, de acordo com o Código Civil de 2002, por Edvaldo Brito e Reginalda Paranhos de Brito. Rio de Janeiro: Forense. 2008. p. 163

${ }^{44}$ Sobre o assunto, veja-se o seguinte esclarecimento: embora faça referência à um dispositivo legal já caduco e substituído pelo estatuto do estrangeiro, lei 6.815 de 19 de agosto de 1980, permanece de atualidade em seu conteúdo: significa dizer que seu ingresso no Brasil há de ter sido feito mediante visto permanente, concedido ao estrangeiro que pretenda fixar-se definitivamente no Brasil, nos termos do artigo 18 do Decreto-lei n. ${ }^{\circ}$ 941/1969. O referido Decreto-lei, em seu artigo 54, define como "permanência" a situação jurídica do estrangeiro no Brasil que se encontre no país sem limitação de tempo. O ordenamento jurídico brasileiro, portanto, não admite a eleição de administrador que tenha ingressado no País simplesmente com visto temporário, pois as hipóteses de concessão desse visto (Decreto-lei n. ${ }^{\circ} 941 / 1969$, artigo 15) são de todo incompatíveis
} 
Apenas para corroborar o que se disse acima, o item 1.2.23.5 do Manual de Registro de Sociedade Limitada aprovado pela Instrução Normativa n. 10, de 05 de dezembro de 2013 do Departamento de Registro Empresarial e Integração esclarece que estrangeiro deverá ter visto permanente e não estar enquadrado em caso de impedimento para o exercício da administração ${ }^{45}$.

Em todo o caso, seja o administrador brasileiro ou não, fará jus ao pagamento de uma retribuição, de um pró-labore, cujo valor deverá ser decidido pelos sócios, no contrato social ou mediante deliberação.

\subsubsection{Permanência e saída do administrador.}

O artigo 1.063 do Código Civil trata do mandato do administrador dispondo que $\mathrm{O}$ exercício do cargo de administrador cessa pela destituição, em qualquer tempo, do titular, ou pelo término do prazo se, fixado no contrato ou em ato separado, não houver recondução. Assim, depreende-se da redação do referido artigo que o mandato do administrador pode ser exercido por prazo indeterminado até que seja destituído ou renuncie.

Essa disposição é contrária ao que prevê a lei das Sociedades Anônimas para o cargo de diretor da diretoria, órgão de administração das sociedades anônimas. De acordo com o diploma legal, os diretores exercerão a gestão do cargo por um mandato de até três anos, permitida a

com o exercício de cargo de gestão social. Dessa forma, embora o legislador aluda apenas à residência, parece que, na prática, continua sendo necessário que o estrangeiro tenha a intenção não somente de morar no Brasil, como também de aqui permanecer, pelo menos, ao longo do período em que esteja no exercício do cargo (PERES, Tatiana Bonatti, Temas Relevantes de Direito Empresarial. In: CRUZ, Gisela Sampaio da; LGOW, Carla Wainer Chalréo. Notas sobre a administração das sociedades limitadas. Rio de Janeiro: Editora Lumen Juris. p. 153-191. Disponível em <http://www.bmalaw.com.br/arquivos/Artigos/11-09 NOTAS_SOBRE_A_ADMINISTRACAO_DAS_SOCIEDADES_LIMITADAS.PDF $>$. Acesso em 01 nov. 2016.

45 1.2.23.5 - Administrador - estrangeiro Administrador estrangeiro deverá ter visto permanente e não estar enquadrado em caso de impedimento para o exercício da administração. 
reeleição ${ }^{46}$. Alguns autores defendem que, caso a sociedade limitada opte pela aplicação supletiva da Lei das Sociedades Anônimas, imperioso faz-se adotar a mesma restrição ao mandato do administrador. Nesse sentido discorre ABRÃO:

Silente o atual Código Civil, a designação do administrador produz, no tempo, a eficácia dos atos jurídicos em geral, isto é, será a estabelecida no contrato, ou indeterminada, caso não ocorram causas extintivas. Doutrinariamente, contudo, entende-se mais consentânea com a excelência do principio da alternância e rotatividade dos poderes a aplicação da norma limitadora do prazo de gestão dos administradores das sociedades anônimas, quando o relativo ao corpo diretivo não for fixado no contrato. No caso, então, seria de invocar o art. 143, III, da Lei das Sociedades por Ações, que limita a duração da gestão por três anos, permitida a recondução, haja, ou não, prazo determinado, contanto que inexista expressa proibição contratual ${ }^{47}$.

Com a devida vênia ao autor, esta não parece ser a melhor interpretação. Defende-se, com o apoio de outros autores, ao contrário, que o cargo do administrador possa ser fixado por prazo determinado ou indeterminado. Nesse prisma, note-se o argumento de CAMPINHO:

A nomeação do administrador poderá realizar-se por prazo certo ou indeterminado. No primeiro caso, expirado o prazo, necessário se mostra a renovação da investidura (recondução) ou a escolha de um substituto ${ }^{48}$.

Ocorre que, neste aspecto, não se trata de omissão do Código Civil e sim e uma norma aberta que não deseja limitar o tempo de atuação do administrador. Até pela própria natureza deste tipo de sociedade, é comum que os próprios sócios sejam os diretores e que a configuração do capital social seja mais estática do que em uma sociedade anônima, de forma que se perde um pouco da razão de limitar o seu mandato no tempo.

Em todo o caso, o mandato do administrador cessa pela sua renúncia. NEGRÃO é muito didático ao ensinar que renuncia do administrador gera efeitos imediatos em relação à Sociedade a partir do conhecimento do ato.

\footnotetext{
${ }^{46}$ Brasil. Lei 6.404 de 15 de dezembro de 1976, artigo 143, inciso III.

${ }^{47}$ ABRÃO Nelson. Sociedades Limitadas. 10. ed. rev. atual e ampl. pelo Desembargador Carlos Henrique Abrão. São Paulo: Saraiva, 2012. p. 168.

${ }^{48}$ CAMPINHO, Sergio. O direito de empresa à luz do novo código civil. 6. Edição revista e atualizada conforme a lei 11.101/2005. Rio de Janeiro: Renovar, 2005. p.223.
} 
No entanto, no que se refere à terceiros, a renúncia gera efeitos a partir do registro do ato no registro competente, o que deve ser feito em dez dias do ocorrido $^{49}$.

Além disso, cessa também o mandato do administrador pela sua destituição. Neste caso, a destituição pode ter por objeto um administrador sócio ou não, nomeado no contrato social ou em ato apartado.

Cumpre ressaltar que independentemente da existência de mandato, o administrador pode ser destituído a qualquer tempo pelos sócios. Nas palavras de ZANETTI, "a revogação do mandatário social é uma regra de ordem pública e são nulas as estipulações em contrário. Os sócios têm um verdadeiro direito de revogação do administrador" $" 50$.

Pelas disposições do Código Civil, no que se refere ao administrador nomeado no corpo do contrato social, sua destituição se opera pelos votos correspondentes a três quartos do capital social, quando se tratar de administrador não sócio e pelos votos de, no mínimo, dois terços do capital social, na hipótese de administrador sócio. Em ambos os casos, note-se, o contrato social poderá prever quóruns diferentes $51 / 52$.

A destituição de administrador nomeado em ato apartado, seja ele sócio ou não, se perfaz pela maioria absoluta do capital social ${ }^{53}$.

\footnotetext{
49 NEGRÃO, Ricardo. Manual de direito comercial e de empresa. volume 1: teoria geral da empresa e direito societário. 12. ed. São Paulo: Saraiva, 2015. p. 413.

${ }^{50}$ ZANETTI, Robson. Manual da sociedade limitada. Curitiba: Juruá, 2007. p 192.

${ }^{51}$ Brasil. Código Civil, artigos 1.071, V e 1.076,I.

${ }^{52}$ ZANETTI, Robson. Op.cit. p 197.

53 Ibid.
} 


\subsubsection{Possibilidade de criação de um conselho de administração nas sociedades limitadas.}

A criação de um conselho de administração não está prevista no Código Civil, de forma que não pode ser considerada norma cogente, como tratou-se até o momento, de requisito formal.

No entanto, graças a aplicação supletiva das normas relativas às sociedades por ações esta é uma possibilidade para as sociedades limitadas, assim também enxerga COELHO: "nada impede que a sociedade limitada adote uma estrutura administrativa complexa, semelhante à da anônima, dotada, por exemplo, de conselho de administração" ${ }^{54}$. No mesmo sentido esclarece CAMPINHO: "não há óbice legal à pretensão dos sócios em implantar na sociedade limitada a figura do conselho de administração" 55 .

Esta possibilidade se afigura como uma verdadeira forma de profissionalização da administração e mudança profunda na estrutura das sociedades limitadas. Como se tratou até o momento, a forma societária das sociedades limitadas é a mais procurada pelos pequenos e médios empresários, muitas vezes sendo os mesmos os administradores das empresas.

Ocorre que, por diversos fatores, a estrutura capitalística de uma sociedade limitada pode rapidamente se tornar complexa à medida que novos sócios vão ingressando. Este fato não obriga que se faça uma transformação da sociedade para uma do tipo por ações. No entanto, é possível que se faça necessário um controle mais apurado dos atos de administração. Nesse sentido, é compreensível e salutar que se possa optar pela criação de um conselho de administração.

\footnotetext{
${ }^{54}$ COELHO, Fábio Ulhoa. Curso de direito comercial. volume 2: direito de empresa. 11. ed., rev. e atual. São Paulo: Saraiva, 2008. p. 441

55 CAMPINHO, Sergio. O direito de empresa à luz do novo código civil. 6. Edição revista e atualizada conforme a lei 11.101/2005. Rio de Janeiro: Renovar, 2005. p.240
} 
Fundamental esclarecer, nas palavras de CAMPINHO que mesmo na vigência de um conselho de administração,

é obstado exercer as funções e competências que o código destinou aos diretores, aos fiscais e à assembleia ou reunião dos sócios. Portanto, não poderá designar ou destituir os diretores da sociedade, visto ser a matéria de deliberação exclusiva dos sócios (artigo 1.071)

Por esse mesmo motivo, há os que não veem grande vantagem em se criar um conselho de administração para sociedades limitadas, posto que esta estrutura jurídica está atrelada à uma menor complexidade do seu funcionamento e estrutura. Este é o pensamento de COELHO:

A criação de um conselho de administração], não é, contudo, muito usual, tendo em vista, inclusive que uma das vantagens da limitada em relação à anônima são os menores custos de manutenção, derivados da maior informalidade da vida societária $^{57}$

\subsection{Normas de conduta no exercício da administração de sociedade limitada à luz dos deveres da Lei das Sociedades Anônimas.}

No item anterior, foram tratados os requisitos, impedimentos e condições para exercer a administração de uma Sociedade Limitada. Chamou-se de requisitos formais.

Nesta etapa, abordar-se-á os deveres de conduta dos administrados. Assim, após confirmação de que os principais deveres dos administradores das sociedades anônimas podem ser utilizados na análise da conduta dos administradores das sociedades limitadas, tais deveres serão analisados individualmente e, sempre que possível, relacionados com as normas do Código Civil.

\footnotetext{
56 CAMPINHO, Sergio. O direito de empresa à luz do novo código civil. 6. Edição revista e atualizada conforme a lei 11.101/2005. Rio de Janeiro: Renovar, 2005. p.240

${ }^{57}$ COELHO, Fábio Ulhoa. Curso de direito comercial. volume 2: direito de empresa. 11. ed., rev. e atual. São Paulo: Saraiva, 2008. p. 442
} 
Os deveres de diligência e lealdade prescritos na Lei das Sociedades Anônimas devem ser interpretados como preceitos gerais, aplicáveis, inclusive, aos administradores de sociedade limitada, ainda que não previstos no Código Civil. Tratam-se de parâmetros de aferição do desempenho dos diretores da limitada. ${ }^{58}$

\subsubsection{O Dever de Diligência}

Pode-se afirmar com tranquilidade que o dever de diligência do administrador da sociedade limitada está exposto no artigo 1.011 do Código Civil que, com efeito, o texto legal ensina que "o administrador da sociedade deverá ter, no exercício de suas funções, o cuidado e a diligência que todo homem ativo e probo costuma empregar na administração de seus próprios negócios".

Esta norma é praticamente idêntica à disposição sobre dever de diligência referida no artigo 153 da lei das Sociedades Anônimas ${ }^{59}$. Destarte, nota-se que o legislador estabeleceu como parâmetros, a atuação do homem ativo e probo. Isto importa dizer que o dever de diligência se inspira no princípio do Bonus Pater Familias, isto é, do bom pai de família.

Contudo, o conceito do Bonus Pater Familias, em tempos modernos já não é mais suficiente para conceituar o dever de diligência. Ocorre que a finalidade de uma sociedade empresária é realizar seu objeto social e promover a obtenção do lucro por meio da tomada de risco, de forma que a atuação meramente cautelosa e cuidadosa do administrador pode não bastar para alcançar estes objetivos.

\footnotetext{
58 Ibid.

${ }^{59}$ Art. 153. O administrador da companhia deve empregar, no exercício de suas funções, o cuidado e diligência que todo homem ativo e probo costuma empregar na administração dos seus próprios negócios.
} 
Assim, o administrador deve tomar diversas decisões que podem se verificar futuramente acertadas ou não, que resultem em lucros ou não. É neste sentido mais amplo da realização do objeto social e do lucro que deve ser compreendida a atuação dos administradores.

O texto legal não expõe com clareza o espírito da lei e deveria fazer referência ao critério de profissionalização do gestor ${ }^{60}$. Isto é, no próprio artigo 152 da Lei das Sociedades Anônimas, o legislador indica que a remuneração do administrador dever ser define tomando em consideração "suas responsabilidades, o tempo dedicado às suas funções, sua competência e reputação profissional".

Tendo em vista que a atuação do administrador envolve a tomada de risco, importante esclarecer que a legislação brasileira não expõe taxativamente os atos a serem praticados pelo administrador para alcançar o dever de diligência, tal medida seria impossível pela enorme complexidade e multiplicidade de atividades empresariais existentes.

Deste modo, o dever de diligência é se refere à uma obrigação de meio e não de resultado, de um princípio geral e norteador do direito brasileiro. $\mathrm{O}$ dever de diligência do administrador vai ser verificado no caso a caso, na condução dos negócios da empresa. Nesse sentido, compartilhase o ensinamento de PARENTE:

Cumpre-se uma obrigação de meio, desde que os comportamentos previstos como obrigatórios tenham sido realizados com a diligência devida, ainda que o objetivo não tenha sido alcançado ou tenha sido atingido de maneira parcial; a obrigação de resultado, ao seu turno, somente é considerada cumprida quando ocorre a prestação em condições de satisfazer o interesse típico do credor. Tendo o administrador uma obrigação de meio e não de resultado, deduz-se que dele é exigível apenas a condução, de maneira diligente, dos negócios sociais de acordo

\footnotetext{
${ }^{60}$ TOLEDO, Paulo Fernando Campos Salles de. $O$ conselho de administração na sociedade anônima: estrutura, funções e poderes, responsabilidade dos administradores. São Paulo: Atlas, 1997. p.54
} 
com o interesse social, tendo em vista os postulados da administração de empresas $^{61}$.

Como norma de conduta aberta, a fim de que se entenda melhor o dever de diligencia em toda sua importância, far-se-á uma breve análise de todos seus aspectos levantados pela doutrina e consolidada jurisprudência, sendo eles: (i) o dever de se qualificar para o exercício da função; (ii) o dever de bem administrar; (iii) o dever de se informar, (iv) o dever de vigiar; e (v) o dever de investigar ${ }^{62}$

\subsubsection{O dever de se qualificar para o exercício da função}

Conforme mencionado acima, o princípio do Bonus Pater Familias não basta para definir o campo de atuação do administrador da sociedade limitada. Assim, para que o administrador esteja nas melhores condições para tomar uma decisão, é necessário que ele se qualifique para o cargo, adaptando suas habilidades conforme o objeto social da sociedade e os bons princípios da administração.

Explica-se, é necessária uma capacidade técnica que ultrapassa o simples cuidado com os negócios da empresa. Ressalva-se que não se impõe ao administrador pleno conhecimento técnico de todas as áreas de atuação de sua empresa, mas é necessária uma competente gestão administrativa, profissional. Assim esclarece EIZIRIK,

O administrador deve ter ou adquirir os conhecimentos mínimos sobre as atividades da companhia e a competência necessária ao desempenho de suas funções, com capacidade técnica par tomar decisões de maneira refletida e responsável. Assim, se o administrador não possui conhecimentos mínimos que lhe permitam dirigir os negócios sociais, não deve aceitar o cargo. ${ }^{63}$

\footnotetext{
${ }^{61}$ PARENTE, Flávia. O dever de diligência dos administradores de sociedade anônimas. Rio de Janeiro: Renovar, 2005. p. 50

${ }^{62}$ Ibid. p. 101

${ }^{63}$ EIZIRIK, Nelson. A Lei das S/A Comentada. São Paulo: Quartier Latin do Brasil, 2011. vol. II. p. 353
} 


\subsubsection{O dever de bem administrar}

O segundo aspecto do dever de diligência decorre também de uma interpretação lógica de dispositivo legal e apresenta-se como um poderdever. Nesse sentido, dispõe o artigo 1.015 do Código Civil que "no silêncio do contrato, os administradores podem praticar todos os atos pertinentes à gestão da sociedade". No mesmo sentido, o artigo 144 da Lei das Sociedades Anônimas prevê que,

No silêncio do estatuto e inexistindo deliberação do conselho de administração (artigo 142, n. II e parágrafo único), competirão a qualquer diretor a representação da companhia e a prática dos atos necessários ao seu funcionamento regular.

Verifica-se, portanto, que os sócios conferem ao administrador os poderes necessários para o cumprimento do objeto social. Nesse sentido, o administrador dispõe de poderes discricionários para realizar o objeto social da sociedade, embora deva sempre se limitar às atividades previstas no contrato.

Ao mesmo tempo em que possui amplos poderes, o administrador é obrigado a gerir a sociedade, seja porque os sócios o constituíram no cargo para tal desempenho, seja porque ele mesmo é órgão que expressa a vontade da sociedade.

Conforme já se mencionou, os atos do administrador devem ser realizados de acordo com a observância do princípio geral da diligência, sendo certo que será julgado pelos sócios e por terceiros apenas com relação a uma obrigação de meio.

Esta relação de poder e dever prevista para os diretores das sociedades anônimas aplica-se supletivamente aos administradores das sociedades limitadas e pode ser mais bem esclarecida nas palavras de PARENTE, “administrar constitui um poder-dever, que reflete o caráter 
fiduciário do cargo de administrador, já que este é o responsável pela gestão do negócio social em nome dos acionistas" $" 64$.

\subsubsection{3. $O$ dever de se informar}

O exercício do cargo de administrador pressupõe a tomada de diversas decisões que buscam realizar a finalidade da empresa. Ao mesmo tempo, é esperado do administrador que ele exerça suas funções de forma diligente. Cumpre, portanto, ao administrador cercar-se do maior volume de informações disponíveis sobre destacado tema para que sua decisão possa ser fundamentada.

Assim, cumpre ao administrador, frente à uma decisão sobre à qual ele mesmo não tenha conhecimento, consultar técnicos e especialistas sobre a questão. Por exemplo, o administrador pode consultar advogados, contadores, técnicos da empresa, consultores externos, entre outros.

Ocorre que, muitas vezes, o exercício da função de administrador de empresa envolve a toda de um enorme fluxo de decisões, de forma que nem sempre há tempo ou recursos suficientes para aceder à maiores informações. Nesse sentido, o dever de se informar requerido ao administrador se mede em função da razoabilidade, do quantum de informações que se podia poderia razoavelmente esperar de um administrador diligente.

Como se vê, não é possível estabelecer uma resposta aplicável a todos os casos de forma genérica e abstrata. Vale dizer, portanto, que compete ao próprio administrador decidir, com base em convicção e quesitos pessoais, o volume de informações necessários para tomar

\footnotetext{
${ }^{64}$ PARENTE, Flávia. O dever de diligência dos administradores de sociedade anônimas. Rio de
} Janeiro: Renovar, 2005. p. 108 
determinada decisão. PARENTE ilustra perfeitamente o dilema do administrador:

Com efeito, se, por um lado, a obtenção de informações adicionais sobre a questão a ser resolvida pode conduzir a decisões mais acertadas, por outro, a solicitação de maiores informações pode implicar elevados custos para a sociedade, não apenas sobre o aspecto financeiro, mas também quando se corre o risco de, eventualmente perder a oportunidade do negócio. ${ }^{65}$

\subsubsection{O dever de vigiar}

Cumpre aos administradores vigiar o andamento geral das atividades da sociedade. Esta norma de conduta se estende a todos os administradores de forma ampla, ainda que diferentes áreas da administração compitam à diferentes administradores, cada qual com sua função. Assim, não se exime da responsabilidade aquele administrador que, por omissão, deixou de vigiar o andamento dos negócios da sociedade, mesmo que a responsabilidade primária seja de outro.

Essa vigilância, portanto, se estende aos atos de responsabilidades de outros administradores, mas também àqueles praticados por subordinados. Ora, não se espera que um administrador seja responsável por todos os departamentos de atuação de uma sociedade.

Em se tratando de sociedade limitada, tem-se por presunção uma maior desburocratização e menor verticalização da estrutura da tomada de poder. Isto pode ser verdade em sociedades iniciantes ou menores, mas à medida em que uma sociedade limitada cresce no mercado, torna-se cada vez mais difícil abrir mão de uma estrutura corporativa mais robusta.

${ }^{65}$ PARENTE, Flávia. O dever de diligência dos administradores de sociedade anônimas. Rio de Janeiro: Renovar, 2005. p. 118 
Assim, é tarefa do administrador contratar subordinados qualificados e competentes para descentralizar a tomada de decisões, supervisionando-os em linhas gerais.

\subsubsection{O dever de investigar}

O dever de investigar decorre daquele de vigiar. Nesse sentido, conforme foi analisado, o administrador tem o dever de vigiar o andamento geral dos negócios e atos da sociedade. Esse dever de vigiar vem acompanhado do dever de se informar. Isto é, os administradores devem possuir análise crítica suficiente para determinar se as informações que lhes foram entregues são suficientemente claras e precisas para formularem opinião.

Ou seja, caso o administrador entenda que não há dúvidas quanto às informações que fornecidas e que não há nada suspeito no andamento dos negócios, não há que se falar no dever de investigar. Veja-se: o dever de investigar só nasce quando há uma desconfiança por parte do administrador na análise das informações. Por esse motivo, é imperioso que o administrador cumpra com seu dever de se informar.

Em encontrando informações suspeitas, ou havendo dúvida, o administrador envidar seus melhores esforços para dirimir aquela dúvida e até de intervir em determinada área de atuação da sociedade para que esta não seja afeta. Deve-se sempre levar em consideração que o administrador é o bastião da sociedade, ele a representa e a protege.

\subsubsection{O Dever de Lealdade e sigilo}

A lei das Sociedades Anônimas trata o dever de sigilo conjuntamente com o dever de lealdade, como se este fosse decorrente daquele. Embora 
esta opção não suscite grande discussão na doutrina ${ }^{66}$, registra-se aqui a crítica de TOLEDO:

Não se justifica, no entanto, essa reunião [do dever de lealdade e do dever de sigilo], e muito menos encontra justificativa o fato de ter o dispositivo apenas o nomen juris do dever de lealdade, como se o dever de sigilo não apresentasse características próprias, sendo somente um apêndice do primeiro. ${ }^{67}$

Ademais, para fins deste estudo, os dois serão abordados adiante conjuntamente, isto porque o dever de sigilo tem como uma de suas finalidades evitar a prática do insider trading, tema que não tem correlação com as sociedades limitadas.

Assim, nas sociedades anônimas com capital aberto há uma necessidade de manter em sigilo algumas informações que possam influenciar de modo considerável a cotação dos valores mobiliários ${ }^{68}$. Nas sociedades limitadas, por outro lado, tal como nas sociedades anônimas com capital fechado, o administrador deve manter todos os sócios informados sobre todas os aspectos relevantes do andamento dos negócios da sociedade.

O dever de lealdade em si, em suma, é a obrigação que deve ser compreendida como o dever de agir na qualidade de órgão representativo da sociedade limitada. Isto é, o administrador deve agir buscando cumprir o objeto social da sociedade, com ética, honra e sentido estrito de dever para com a sociedade e seus sócios. A lei das Sociedades Anônima elenca alguns exemplos de atos que ferem o dever de lealdade:

\footnotetext{
${ }^{66}$ Nesse sentido, NETO discorre que "A lealdade encarna o significado de compromisso ético e tem intima ligação com um outro dever, que é o de atuar com discrição, isto é, com reserva e sigilo sobre os negócios da companhia que só possam ou devam ser do conhecimento daqueles que os presenciam ou que, em razão do cargo que ocupam, devem conhece-lo" (NETO, Alfredo de Assis Gonçalves. Manual das companhias ou sociedades anônimas. 2. ed. reformulada da obra Lições de Direito Societário II - Sociedade Anônima. São Paulo: Editora Revista dos Tribunais, 2010. p. 197).

${ }^{67}$ TOLEDO, Paulo Fernando Campos Salles de. $O$ conselho de administração na sociedade anônima: estrutura, funções e poderes, responsabilidade dos administradores. São Paulo: Atlas, 1997. p. 57

${ }^{68}$ BRASIL. Lei 6.404 de 15 de dezembro de 1976, artigo 155, parágrafo $1^{\circ}$.
} 
Art. 155. O administrador deve servir com lealdade à companhia e manter reserva sobre os seus negócios, sendo-lhe vedado:

I - usar, em benefício próprio ou de outrem, com ou sem prejuízo para a companhia, as oportunidades comerciais de que tenha conhecimento em razão do exercício de seu cargo;

II - omitir-se no exercício ou proteção de direitos da companhia ou, visando à obtenção de vantagens, para si ou para outrem, deixar de aproveitar oportunidades de negócio de interesse da companhia;

III - adquirir, para revender com lucro, bem ou direito que sabe necessário à companhia, ou que esta tencione adquirir.

A proibição de praticar tais atos, por certo, se aplica ao bom exercício da administração nas sociedades limitadas. Conclui-se assim, relacionando o dever de lealdade e sigilo com o dever de diligência já que ambos se baseiam na ética e na confiança, sendo aquele complementar a este. Isto é, quando o administrador agir com lealdade e sigilo, para responsabiliza-lo será necessário provar quebra do dever de diligencia em algum dos seus aspectos ${ }^{69}$.

\subsubsection{O Dever de Informação}

Conforme amplamente repetido ao longo deste estudo, a Lei das Sociedades Anônimas aplica-se às sociedades limitadas apenas de forma supletiva e somente no que for compatível.

Sendo assim, objetivamente o dever de informação previsto no referido dispositivo legal não encontra aplicação para as sociedades limitadas. Isto porque a doutrina é unânime em afirmar tratar-se de uma norma exclusiva para sociedades anônimas de capital aberto.

${ }^{69}$ PARENTE, Flávia. O dever de diligência dos administradores de sociedade anônimas. Rio de Janeiro: Renovar, 2005. p. 177-178 
Nesse sentido, NETO propõe que "há ainda, um outro dever importante [o dever de informar], do qual os administradores de companhia fechada são dispensados"70. PARENTE vai além:

Outro dever fundamental imposto pela Lei das Sociedades Anônimas aos administradores encontra-se previsto no artigo 157 sob a rubrica de "dever de informar". Tal dispositivo tem como destinatários, exclusivamente, os administradores das companhias abertas, aquelas cujos valores mobiliários estão admitidos à negociação do mercado de valores mobiliários. ${ }^{71}$

Isto posto, cumpre dizer que o artigo 1.020 do Código Civil impõe aos administradores obrigação de prestar informações aos sócios: (i) contas justificadas de sua administração; (ii) inventário anual; (iii) balanço patrimonial e o de resultado econômico.

Defende-se, portanto, que embora o dever de informação previsto na Lei das Sociedades Anônimas não se aplique diretamente às sociedades limitadas, os administradores têm para com os sócios da sociedade uma obrigação de mantê-los informados.

Entende-se ainda que os administradores devam informar os sócios sobre quaisquer pontos relevantes na condução dos negócios da sociedade, cumprindo fielmente com seu dever de diligência e lealdade.

\subsubsection{O dever negativo de não se colocar em posição de conflito de interesses}

Ao passo que os demais deveres do administrador analisados aqui constituem uma norma de conduta positiva, a questão do conflito de interesses é colocada como uma norma de conduta negativa. Interessante pontuar que o legislador optou por não definir quais atos que constituiriam

\footnotetext{
${ }^{70}$ NETO, Alfredo de Assis Gonçalves. Manual das companhias ou sociedades anônimas. 2. ed. reformulada da obra Lições de Direito Societário II - Sociedade Anônima. São Paulo: Editora Revista dos Tribunais, 2010. p. 199.

${ }^{71}$ PARENTE, Flávia. O dever de diligência dos administradores de sociedade anônimas. Rio de Janeiro: Renovar, 2005. p. 209
} 
um conflito de interesse, deixando tal missão para o próprio administrador, que deve declarar seu impedimento para praticar determinado ato. ${ }^{72}$

Ressalta-se tampouco, que a lei não proíbe o administrador de contratar com a sociedade, embora não possa interver no negócio. Nas palavras de TOLEDO:

Veda-lhe [o administrador], apenas, que intervenha, na qualidade de administrador, no ato negocial. E isso porque, se interviesse, estaria, se diretor, atuando ao mesmo tempo como representante orgânico da companhia (evidentemente dispondo de poderes para tanto) e da outra parte (se pessoa jurídica) [...] é inegável a incompatibilidade: não pode a mesma pessoa assumir, simultaneamente, posições conflitantes. ${ }^{73}$

Ademais, em caso de contratação com a sociedade, impõe a lei que tal negócio seja feito em condições de normais de mercado. No conflito de interesses falta ao administrador a imparcialidade necessária para fazer valer a voz da sociedade, agir na qualidade de órgão representativo.

O administrador deve agir com lealdade e informação para com os sócios e demais administradores e avisar do impedimento para que a sociedade tome uma decisão independente. Ao final, o que se espera com essa regra de conduta negativa é proteger o interesse social da sociedade.

72 Art. 156. É vedado ao administrador intervir em qualquer operação social em que tiver interesse conflitante com o da companhia, bem como na deliberação que a respeito tomarem os demais administradores, cumprindo-lhe cientificá-los do seu impedimento e fazer consignar, em ata de reunião do conselho de administração ou da diretoria, a natureza e extensão do seu interesse. $\S 1^{\circ}$ Ainda que observado o disposto neste artigo, o administrador somente pode contratar com a companhia em condições razoáveis ou equiitativas, idênticas às que prevalecem no mercado ou em que a companhia contrataria com terceiros. $\S 2^{\circ} \mathrm{O}$ negócio contratado com infração do disposto no $\S 1^{\circ}$ é anulável, e o administrador interessado será obrigado a transferir para a companhia as vantagens que dele tiver auferido.

73 TOLEDO, Paulo Fernando Campos Salles de. $O$ conselho de administração na sociedade anônima: estrutura, funções e poderes, responsabilidade dos administradores. São Paulo: Atlas, 1997. p. 61 


\section{CAPITULO 3 - DA RESPONSABILIDADE CIVIL DO ADMINISTRADOR}

Neste Capítulo final, estudar-se-á a responsabilidade dos administradores das sociedades limitadas prevista no Código Civil com apoio das normas referentes às sociedades anônimas. Importante dizer que este estudo terá enfoque apenas na responsabilidade civil dos administradores posto ser este objeto das referências legais analisadas. Assim, em um primeiro momento será relembrada rapidamente a noção de responsabilidade civil do nosso Código, para somente então adentrar nas hipóteses de responsabilidade dos administradores.

\subsection{Responsabilidade Civil}

\subsubsection{Previsão no Código Civil}

Acerca da responsabilidade civil, nosso Código dispõe que aquele que causar dano a outrem por ato ilícito, fica obrigado a repará-lo ${ }^{74}$. Logo, trata-se aqui de uma obrigação ou penalização patrimonial. Resta saber ao que se refere o ato ilícito.

O Código civil define duas hipóteses de ato ilícito. A primeira é aquela em que o agente, "por ação ou omissão voluntária, negligência ou imprudência, violar direito e causar dano a outrem, ainda que exclusivamente moral"75. Já a segunda hipótese se refere ao agente "titular de um direito que, ao exercê-lo, excede manifestamente os limites impostos pelo seu fim econômico ou social, pela boa-fé ou pelos bons costumes"76. Nas palavras de PEREIRA:

\footnotetext{
74 BRASIL. Código Civil, artigo 927.

${ }^{75}$ BRASIL. Código Civil, artigo 186

${ }^{76}$ BRASIL. Código Civil, artigo 187
} 
O fundamento maior da responsabilidade civil está na culpa. É fato comprovado que se mostrou esta insuficiente para cobrir toda a gama dos danos ressarcíveis; mas é fato igualmente comprovado que, na sua grande maioria, os atos lesivos são causados pela conduta antijurídica do agente, por negligencia ou por imprudência. $^{77}$

A responsabilidade civil pautada na culpa é comumente denominada teoria subjetiva. É principalmente com base nesta ótica de responsabilidade civil que deverá ser analisada a responsabilidade dos administradores. Contudo, como se verá adiante, há casos de responsabilidade sem culpa, a chama teoria objetiva, que eventualmente também se aplica aos administradores.

\subsubsection{Elementos da responsabilidade civil conforme a teoria subjetiva, confronto com a teoria objetiva.}

Pode-se dizer que são elementos da responsabilidade civil, conforme a teoria subjetiva: (i) dano; (ii) culpa; e (iii) nexo de causalidade.

O dano, nos dizeres de MULHOLLAND,

sempre foi considerado como o elemento essencial da responsabilidade civil - o seu pressuposto inarredável -, sem o qual sequer se pode referir à obrigação de indenizar. Se a indenização é o "desfazimento do dano", sem que este se realize não haverá a responsabilidade civil, mesmo que a conduta operada pelo ofensor seja das mais dolosas. Sem prejuízo não há dano, e sem dano não há responsabilidade. ${ }^{78}$

No que se refere à culpa, enquanto na teoria subjetiva trata-se de uma condição sine qua non, na teoria objetiva, se prescinde dela para gerar a obrigação de indenizar. Para PEREIRA, a culpa é fundada em um "erro de conduta ou transgressão de uma regra predeterminada, seja de natureza

\footnotetext{
${ }^{77}$ PEREIRA, Caio Mário da Silva. Instituições de direito civil. Rio de Janeiro, Editora Forense, 2010. p. 506

${ }^{78}$ MULHOLLAND, Caitlin Sampaio. A responsabilidade civil por presunção de causalidade. Rio de Janeiro: GZ Ed., 2009. p. 24
} 
contratual, seja de natureza extracontratual"79. O autor esclarece ainda que para a teoria objetiva, há uma

abstração da ideia de culpa, estabelecendo ex-lege a obrigação de reparar o dano, desde que fique positivada a autoria de um comportamento, sem necessidade de se indagar se foi ou não foi contrário à predeterminação de uma norma. ${ }^{80}$

Por fim, o último elemento da responsabilidade civil, presente tanto na teoria subjetiva quanto na teoria objetiva é o do nexo causal. Aqui não se trata de verificar culpa ou não, mas sim a relação entre uma ação ou omissão e o dano causado. Não havendo este indispensável elo, não se caracteriza a responsabilidade civil. MULHOLLAND esclarece o tema:

O nexo de causalidade é ao mesmo tempo o componente da obrigação de indenizar que serve a identificar o responsável por reparar o dano - através do estabelecimento de uma ligação de causa e efeito entre uma conduta ou atividade e o dano que se visa reparar -, e o limitador do quantum indenizatório - através da demarcação das verbas indenizáveis. Percebe-se com isto que a pesquisa e delimitação do nexo de causalidade são as funções mais relevantes e, porque não, instransponíveis no estabelecimento da responsabilidade civil, na medida em que se não for possível realizar-se esta conexão entre agente e dano não se terá estabelecida a obrigação de indenizar. ${ }^{81}$

A partir destas noções básicas acerca da responsabilidade civil será possível analisar a responsabilidade dos administradores. Adianta-se que nossa legislação adotou ora a teoria subjetiva, ora a teoria objetiva.

\subsection{Responsabilidade dos administradores}

Conforme já estudado, via de regra, os administradores possuem os mais amplos poderes para obrigar a sociedade a fim de alcançar a sua finalidade social. Viu-se também, que tais poderes vêm acompanhados de diversos deveres, sendo o maior deles o de diligência. Tendo em vista este binômio poder/dever, faz-se necessário verificar em que medida os

\footnotetext{
${ }^{79}$ PEREIRA, Caio Mário da Silva. Instituições de direito civil. Rio de Janeiro, Editora Forense, 2010. p. 511

${ }^{80} \mathrm{Ibid}$.

${ }^{81}$ MULHOLLAND, Caitlin Sampaio. A responsabilidade civil por presunção de causalidade. Rio de Janeiro: GZ Ed., 2009. p. 57-58.
} 
administradores ficam pessoalmente responsáveis pelos atos que praticam enquanto órgão de representação da sociedade.

De um lado, o Código Civil norteia a atuação do administrador no sentido de que os atos praticados regularmente com observância dos seus deveres não obrigam o administrador pessoalmente.

Nesse sentido artigo 1.012 dispõe que o administrador nomeado em ato apartado responde pessoal e solidariamente pelos atos praticados antes da averbação do ato. Em sentido contrário, entende-se que após o registro do ato o administrador não mais responde pessoalmente. $\mathrm{O}$ mesmo entendimento vale, logicamente para o administrador nomeado no próprio contrato social.

VERÇOSA complementa o argumento acima, sustentando que a o fato de os atos praticados pelos administradores não os vincularem pessoalmente decorre da prevalência da teoria organicista, já tratada neste estudo, segundo a qual é a própria sociedade que contraí manifesta sua vontade e contraí obrigação. O administrador não é um mero mandatário. ${ }^{82}$

Por outro lado, via de regra, os administradores somente vão responder perante a sociedade e terceiros prejudicados, por culpa no desempenho de suas funções ${ }^{83}$. Nesse sentido, têm-se, de acordo com o parágrafo segundo do artigo 158 da Lei das Sociedades Anônimas que:

Os administradores são solidariamente responsáveis pelos prejuízos causados em virtude do não cumprimento dos deveres impostos por lei para assegurar o funcionamento normal da companhia, ainda que, pelo estatuto, tais deveres não caibam a todos eles.

\footnotetext{
${ }^{82}$ VERÇOSA, Haroldo Malheiros Duclerc. Direito Comercial. v.3. 3. ed rev., atual e ampl. São Paulo: Editora Revista dos Tribunais, 2014. p. 422

${ }^{83}$ BRASIL. Código Civil, artigo 1.016
} 
Além disso, embora não esteja expressamente previsto no Código Civil, deve-se aplicar supletivamente a regra geral prevista no artigo 158 da Lei das Sociedades Anônimas:

Art. 158. O administrador não é pessoalmente responsável pelas obrigações que contrair em nome da sociedade e em virtude de ato regular de gestão; responde, porém, civilmente, pelos prejuízos que causar, quando proceder:

I - dentro de suas atribuições ou poderes, com culpa ou dolo;

II - com violação da lei ou do estatuto.

DINIZ defende a aplicação supletiva das regras de responsabilidade do administrador previstas no artigo 158 da Lei das Sociedades Anônimas e é transparente ao afirmar:

Via de regra, o administrador [de sociedade limitada] não tem responsabilidade pessoal pelas obrigações que contrair em nome da sociedade e em decorrência de regulares atos de gestão empresarial (art.158 da LSA e art. 10 do Decreto n. 3.708/19). A exceção desta regra é a responsabilidade civil pessoal do administrador quando atuar: a) dentro de suas atribuições ou poderes, com culpa ou dolo; b) com violação da lei ou do estatuto, tratando-se também de responsabilidade subjetiva, conforme entende majoritária doutrina. ${ }^{84}$

Interessante notar aqui que DINIZ defende uma responsabilidade subjetiva em quaisquer dos casos previstos nos incisos I e II do artigo supra. Este não é o pensamento de TOLEDO que entende ser subjetiva a responsabilidade em caso de infração ao inciso I e objetiva em relação ao inciso II. Por suas palavras:

Assim, a hipótese do art. 158, inciso I, da Lei das Sociedades por Ações, assemelha-se à do art. 159 do Código Civil. Tanto num caso, como no outro o que se prevê é a responsabilidade do agente pelos prejuízos causados por sua conduta, sempre que tenha agido com dolo ou culpa. Imprescindível, logo se vê, a análise do elemento subjetivo, incumbido àquele que sofreu o dano a prova da culpa (lato sensu) com que agiu o sujeito ativo. ${ }^{85}$

\section{E prossegue:}

A principal característica do ato agora examinado [o ato praticado pelo administrador em violação da lei ou do estatuto] é a de que, nesses casos, o

\footnotetext{
84 DINIZ, Gustavo Saad. Responsabilidade dos administradores por dívidas das sociedades limitadas. Porto Alegre: Síntese, 2003. p. 103

85 TOLEDO, Paulo Fernando Campos Salles de. O conselho de administração na sociedade anônima: estrutura, funções e poderes, responsabilidade dos administradores. São Paulo: Atlas, 1997. p. 68
} 
reconhecimento da responsabilidade independe do exame do elemento subjetivo. Com efeito, para se ter por descumprida uma lei ou o estatuto de uma companhia, não é preciso saber, em geral, o ânimo que presidiu a conduta do agente.

De toda forma, a culpa do administrador deve ser verificada no descumprimento de seus deveres estudados no capítulo anterior.

Neste estudo adota-se o entendimento segundo o qual o administrador responde por culpa ou dolo no desempenho de suas funções regulares e objetivamente quando em violação do contrato ou da lei. Necessário, portanto, necessário verificar os efeitos destes atos praticados pelos administradores. Para isso, cumpre analisar as teorias intra vires, ultra vires e a teoria da aparência.

\subsubsection{Teoria Intra Vires e Ultra Vires}

Os poderes gerais do administrador decorrentes da lei ou do contrato são comumente chamados de poderes intra vires. São os poderes de gestão e de tomada de decisões. Por estes, como já mencionado, o administrador só vai responder pessoalmente em caso de falha nos seus deveres.

No entanto, pode ser que o administrador pratique atos que ultrapassam os seus poderes intra vires, são os chamados atos ultra vires. Entende-se que a sociedade existe apenas para cumprir sua finalidade social e, para isso, é necessário a presença de um órgão administrativo dotados de poderes suficientes, mas não ilimitados.

Assim, os atos praticados pelo administrador em contrariedade com aqueles outorgados pela lei ou pelo contrato tem como consequência a quebra da fidúcia existente entre os sócios e o administrador e, portanto, a perda da garantia de proteção ao seu patrimônio em caso de dano à sociedade ou terceiros. 
Cumpre ressaltar que determinados atos ultra vires, podem ser praticados pelos administradores, desde que com autorização prévia dos sócios. É o caso da oneração ou venda de imóveis - quando esta operação não constituir objeto social - e a aplicação de créditos ou bens sociais em proveito próprio ou de terceiros ${ }^{86}$. Assim, basta que o administrador obtenha o aval dos sócios para que não responda pessoalmente pelas obrigações assumidas.

\subsubsection{Eficácia dos atos ultra vires}

Classicamente, os atos ultra vires são considerados nulos, uma vez que a sociedade não possui os poderes e a capacidade para praticá-los. Essa visão já não se aplica em nosso ordenamento "em face da tutela dos interesses dos terceiros de boa-fé, bem como em razão da segurança das relações jurídicas". 87

O Código Civil abarca a teoria ultra vires de forma mitigada já que, em princípio, os atos praticados pelo administrador, mesmo que em desacordo com os limites do contrato social, obrigam a sociedade. No entanto, é possível que a sociedade oponha os excessos do administrador, de forma a anular os atos praticados em três circunstancias, conforme se destaca do artigo 1.015 do Código Civil:

\footnotetext{
Art. 1.015. No silêncio do contrato, os administradores podem praticar todos os atos pertinentes à gestão da sociedade; não constituindo objeto social, a oneração ou a venda de bens imóveis depende do que a maioria dos sócios decidir.

Parágrafo único. O excesso por parte dos administradores somente pode ser oposto a terceiros se ocorrer pelo menos uma das seguintes hipóteses:

I - se a limitação de poderes estiver inscrita ou averbada no registro próprio da sociedade;

II - provando-se que era conhecida do terceiro;

III - tratando-se de operação evidentemente estranha aos negócios da sociedade.
}

\footnotetext{
${ }^{86}$ Brasil. Código Civil, artigos 1.015 e 1.017

${ }^{87}$ CALÇAS, Manoel de Queiroz Pereira. Sociedade limitada no novo código civil. São Paulo: Atlas, 2003. p. 151
} 
CALÇAS, faz duras críticas à teoria ultra vires, ainda que esta seja aplicada de forma apenas mitigada. Para o autor, com base na teoria organicista, não é possível separar a vontade do administrador da vontade da sociedade, devendo esta responder por todos os atos daquele perante terceiros. O autor prossegue esclarecendo que o terceiro de boa-fé deve ficar sempre protegido na relação jurídica. ${ }^{88}$

Absorvidas as críticas acima expostas, sustenta-se, neste estudo, que o terceiro de boa-fé de fato deve ser protegido. No entanto, as hipóteses de anulabilidade dos atos do administrador não parecem afastar a relação de boa-fé. Ao contrário, permite a sociedade provar que o agente não estava agindo com base nos preceitos éticos das relações comerciais.

Assim, a boa-fé do terceiro será atestada com base na teoria da aparência que surgiu como uma contraposição da teoria ultra vires, inclusive aquela mitigada, como será abordado a seguir.

\subsubsection{Teoria da aparência.}

A teoria da aparência sustenta que todos os atos praticados pela sociedade devem ter sociedade, ainda que o administrador tenha agido com excesso de poderes. Isto porque, nas relações comerciais nem sempre é possível cercar-se de todos os instrumentos necessários a fim de analisar se o administrador de determinada sociedade tem todos os poderes necessários para pratica de um negócio jurídico. Esta teoria privilegia a boa-fé objetiva nas relações contratuais e o princípio da transparência e lealdade. ${ }^{89}$

\footnotetext{
${ }^{88}$ CALÇAS, Manoel de Queiroz Pereira. Sociedade limitada no novo código civil. São Paulo: Atlas, 2003. p. 153

${ }^{89}$ PEREIRA, Paula Moura Francesconi de Lemos, A responsabilidade da sociedade empresária e do empresário pelos atos dos administradores. p. 28 Disponível em < http://www.publicadireito.com.br/artigos/?cod=b986700c627db479>. Acesso em 01 out. 2016.
} 
Parece que a Lei das Sociedade Anônimas adotou somente a teoria da aparência já que não há dispositivo que preveja a anulação de qualquer ato praticado pelo Administrador. Nesse sentido CALÇAS expõe que:

Se a sociedade limitada for regida supletivamente pela Lei das Sociedades por Ações, não poderá invocar a teoria ultra vires, mesmo mitigada, em relação à terceiros, cabendo à sociedade responder pelos atos ilícitos que seus administradores praticarem no exercício da gestão. ${ }^{90}$

Com respeito à opinião do autor, não parece ser esta a melhor reflexão. Com efeito, o Código Civil previu aplicação apenas supletiva à Lei das Sociedades Anônimas, não subsidiária. Nesse sentido, aplica-se a referida lei especial apenas nas omissões do Código Civil. Ocorre que está expressamente previsto no Código Civil que em determinados casos a sociedade pode opor o excesso aos terceiros.

Sendo assim, entende-se pela aplicação da teoria ultra vires mitigada que tem como regra geral a validade de todos os atos praticados pelos administradores, embora contenha exceções.

Ademais, a teoria da aparência não deve ser totalmente afastada posto que os terceiros de boa-fé devem ter resguardados os negócios firmados. Nesse sentido, o terceiro que adotar um standard de diligência na condução dos negócios poderá forçar a validade de determinado ato jurídico ainda que praticado com excesso pelo administrador. Caberá apenas demonstrar que o terceiro foi razoavelmente diligente ao contratar com a sociedade.

${ }^{90}$ CALÇAS, Manoel de Queiroz Pereira. Sociedade limitada no novo código civil. São Paulo: Atlas, 2003. p. 153 


\subsection{Responsabilidade do administrador em administração coletiva.}

Via de regra, a responsabilidade de cada administrador é individual, devendo cada um responder pessoalmente pelas suas ações ou omissões ${ }^{91}$. Além disso, o Código Civil dispõe que competindo a administração individualmente a cada administrador, é possível impugnar operação pretendida por um administrador, cabendo aos sócios decidirem sobre a matéria por maioria de $\operatorname{votos}^{92}$

Pode ocorre ainda que a administração seja exercida pela expressão de vontade uma maioria de administradores. Nesse caso, visto que o Código Civil nada dispõe sobre o tema, deve-se aplicar o parágrafo primeiro do artigo 158 da Lei das Sociedades Anônimas supletivamente, que determina:

O administrador não é responsável por atos ilícitos de outros administradores, salvo se com eles for conivente, se negligenciar em descobri-los ou se, deles tendo conhecimento, deixar de agir para impedir a sua prática. Exime-se de responsabilidade o administrador dissidente que faça consignar sua divergência em ata de reunião do órgão de administração ou, não sendo possível, dela dê ciência imediata e por escrito ao órgão da administração, no conselho fiscal, se em funcionamento, ou à assembleia-geral.

Vê-se que a lei prevê casos em que o administrador será solidariamente responsável pela prática de um ato de outro administrador, quando com ele for conivente, negligente ou omisso. Denota-se neste dispositivo uma clara menção à uma violação dos deveres de vigiar e investigar inerentes ao dever de diligência dos administradores, mas não somente. A conivência é o conluio entre os administradores, destaca-se por ser uma conduta refletiva quiçá dolosa.

Com relação às companhias, VERÇOSA destaca que:

\footnotetext{
${ }^{91}$ VERÇOSA, Haroldo Malheiros Duclerc. Direito Comercial. v.3. 3. ed rev., atual e ampl. São Paulo: Editora Revista dos Tribunais, 2014. p. 424

${ }^{92}$ BRASIL. Código Civil, artigo 1.103, parágrafo $1^{\circ}$.
} 
Em uma pequena sociedade anônima dirigida por dois diretores este dever de fiscalização é intenso e a diligência no sentido do seu comportamento revela-se fácil, tanto quanto a prova de negligencia ${ }^{93}$

Este mesmo comentário pode se aplicar às sociedades limitadas que, em geral, têm uma estrutura corporativa mais enxuta. Deste modo, em uma sociedade limitada de pequeno porte, o standard de conduta esperado de um administrador é elevado.

\subsection{Outros casos de responsabilidade do administrador.}

\subsubsection{Omissão no uso da expressão "Limitada"}

O Código Civil dispõe que incorre em responsabilidade solidária e ilimitada o administrador que fizer uso da firma ou denominação social da sociedade omitindo a expressão "Limitada" ao final.

Ora, da maneira como a norma está redigida, parece que a responsabilidade do administrador nesta violação é objetiva e independe de culpa. Parece um enorme exagero impor tamanha penalidade por esta omissão. Entende-se que o mais razoável é que o prejudicado deva comprovar que foi iludido pela omissão e demonstrar o prejuízo causado. ZANETTI reforça este entendimento:

É um exagero afirmar que, se o administrador não utilizar a palavra limitada ou sua abreviatura "Itda." em sua denominação ou firma social, ele responderá solidária e ilimitadamente pelas obrigações sociais ("CCC/2002, art. $1.158, \S 3^{\circ}$ ), porque não foi diligente neste sentido.

Caso não conste o termo "limitada" (hipótese rara), deve-se verificar seu conteúdo para saber se a intenção dos sócios é de construir uma sociedade limitada e assim serem feitas as adaptações necessárias para ver se, após o registro e exercício das atividades, as pessoas que com ela contrataram presumiam que estavam contratando com este tipo societário. A presunção é a regra, pois a esmagadora maioria das sociedades tem a forma limitada ${ }^{94}$.

\footnotetext{
${ }^{93}$ VERÇOSA, Haroldo Malheiros Duclerc. Direito Comercial. v.3. 3. ed rev., atual e ampl. São Paulo: Editora Revista dos Tribunais, 2014. p. 424

${ }^{94}$ ZANETTI, Robson. Manual da sociedade limitada. Curitiba: Juruá, 2007. p 221
} 


\subsubsection{Operações em desacordo com a maioria}

Nesta hipótese, o administrador que detém os poderes para representar a sociedade a obriga em circunstancia em que a maioria dos demais administradores eram contrários ${ }^{95}$. Impõe-se razoavelmente que o administrador consulte seus pares para a tomada de uma decisão. Este dever de diligencia e vigilância se faz ainda mais presente em uma sociedade de estrutura simplificada, como normalmente é o caso das sociedades limitadas.

Cumpre ressaltar que, em caso de urgência e perigo de dano grave e irreparável para a sociedade, o administrador deve tomar todas as medidas necessárias, ainda que sem os poderes necessários, para afastar este perigo.

\footnotetext{
${ }^{95}$ BRASIL. Código Civil, artigo 1.013, parágrafo $2^{\circ}$
} 


\section{CONCLUSÃO}

Ao longo deste trabalho buscou-se entender a administração das sociedades limitadas à luz das normas previstas na Lei de Sociedades Anônimas.

Conforme tratado repetidamente, a sociedade limitada é a espécie societária mais escolhida pelo empresário que se arrisca em uma atividade comercial. Ocorre que, por descuido do Código Civil, o tema não foi tratado com o devido zelo, de forma que as normas pertinentes são incompletas para resolver todas as situações que decorrem da vida complexa de uma sociedade limitada.

Uma crítica que se faz, então, é que as sociedades limitadas, ou empresárias, poderiam ter sido contempladas por uma legislação específica, tal como as sociedades por ações o foram. O fato é que o operador do direito, ao tratar das sociedades limitadas, deve buscar apoio normativo nas regras das sociedades simples e, à escolha dos sócios, nas regras das sociedades anônimas.

Assim, tem-se que a previsão de aplicação supletiva das normas das sociedades anônimas tem papel decisivo no desenvolvimento das sociedades limitadas.

Conforme abordado, a aplicação supletiva da lei das sociedades anônimas deve ser uma opção dos sócios e não pode se sobrepor à temas que não caibam ao crivo dos sócios.

Assim, em resumo, buscou-se demonstrar que, ao escolher aplicar supletivamente a lei das sociedades anônimas, os sócios aceitam a 
incidência automática de todas as normas de princípios cabíveis. Ao reverso, para que sejam utilizados instrumentos cabíveis como o conselho de administração, é necessária a decisão expressa dos sócios.

Mostrou-se também que o Departamento de Registro Empresarial e Integração optou por limitar a aplicação dos instrumentos previstos na Lei das Sociedades Anônimas, como, por exemplo, a criação de quotas preferenciais.

Embora tradicionalmente as sociedades limitadas sejam menos complexas que as sociedades anônimas, não é incomum que estas sociedades se desenvolvam e devam adotar medidas corporativas que são próprias às sociedades anônimas.

Uma destas medidas é contar com uma administração eficiente e diligente. Assim, as normas de orientação de conduta dos diretores previstas na lei das sociedades anônimas devem ser incorporadas ao máximo nas sociedades limitadas.

Assim, de um lado, os sócios da sociedade limitada podem contar com a atuação de um profissional capaz de lidar com situações para as quais, os sócios, possivelmente, não estejam preparados.

Por outro lado, o administrador tem norteado o exercício de sua atividade, para que não se veja responsável pessoalmente por atos regulares de gestão.

Cumpre ressaltar que ao administrador não é imputada a obrigação de acertar em todas suas decisões, mas sim de agir com zelo e empenho, norteado principalmente pelos deveres de diligência e lealdade. 
Relembra-se ainda, que nossa legislação adotou critérios de responsabilidade objetiva e critérios de responsabilidade subjetiva, que dependem de culpa ou dolo.

Assim, em se tratando de responsabilidade subjetiva, é importante analisar cuidadosamente os principais deveres dos administradores previstos na Lei das Sociedades Anônimas, para determinar a responsabilidade dos administradores.

Por fim, reforça-se aqui a necessidade de se ter uma legislação própria e específica, capaz de dirimir as dúvidas do operador do direito e simplificar a atuação do empresário, promovendo o desenvolvimento econômico. Nesse sentido, aguarda-se ansiosamente a chegada de um novo Código Comercial à altura da expectativa. 


\section{BIBLIOGRAFIA}

ABRÃO Nelson, Sociedades Anônimas. Sociedades Limitadas. 10. ed. rev. atual e ampl. pelo Desembargador Carlos Henrique Abrão. São Paulo: Saraiva, 2012. $386 \mathrm{p}$.

ALVES, Alexandre Ferreira de Assumpção. A Pessoa Jurídica e os Direitos da Personalidade. Rio de Janeiro: Renovar, 1998. 143p.

BORBA, José Edwaldo Tavares. Direito societário. 13.ed. rev. e atual. Rio de Janeiro: Renovar, 2012. 595p.

CALÇAS, Manoel de Queiroz Pereira. Sociedade limitada no novo código civil. São Paulo: Atlas, 2003. p. 151

CAMPINHO, Sergio. O direito de empresa à luz do novo código civil. 6. Edição revista e atualizada conforme a lei 11.101/2005. Rio de Janeiro: Renovar, 2005. $373 p$.

COELHO, Fábio Ulhoa. Curso de direito comercial, volume 1. 9. ed., rev. e atual. São Paulo: Saraiva, 2005. 507p.

COELHO, Fábio Ulhoa. Curso de direito comercial, volume 2: direito de empresa. 11. ed., rev. e atual. São Paulo: Saraiva, 2008.

DINIZ, Gustavo Saad. Responsabilidade dos administradores por dívidas das sociedades limitadas. Porto Alegre: Síntese, 2003. 228p.

EIZIRIK, Nelson. A Lei das S/A Comentada. São Paulo: Quartier Latin do Brasil, 2011. vol. II. pág. 353 
FAZZIO Junior, Waldo, Lei de falência e recuperação de empresas. 6. ed. São Paulo: Atlas, 2012.

GOMES, Orlando. Introdução ao direito civil. Revista, atualizada e aumentada, de acordo com o Código Civil de 2002, por Edvaldo Brito e Reginalda Paranhos de Brito. Rio de Janeiro: Forense. 2008.

MULHOLLAND, Caitlin Sampaio, A responsabilidade civil por presunção de causalidade. Rio de Janeiro: GZ Ed., 2009. 374p.

NEGRÃO, Ricardo. Manual de direito comercial e de empresa, volume 1: teoria geral da empresa e direito societário. 12. ed. São Paulo: Saraiva, 2015. 578p.

NETO, Alfredo de Assis Gonçalves. Manual das companhias ou sociedades anônimas. 2. ed. reformulada da obra Lições de Direito Societário II - Sociedade Anônima. São Paulo: Editora Revista dos Tribunais, 2010.

PARENTE, Flávia. O dever de diligência dos administradores de sociedade anônimas. Rio de Janeiro: Renovar, 2005. 260p.

PEREIRA, Caio Mário da Silva, Instituições de direito civil. Rio de Janeiro, Editora Forense, 2010

PEREIRA, Paula Moura Francesconi de Lemos, A responsabilidade da sociedade empresária e do empresário pelos atos dos administradores. Disponível em http://www.publicadireito.com.br/artigos/?cod=b986700c627db479>. Acesso em 01 out. 2016

PERES, Tatiana Bonatti, Temas Relevantes de Direito Empresarial. In: CRUZ, Gisela Sampaio da; LGOW, Carla Wainer Chalréo, Notas sobre a administração 
das sociedades limitadas. Rio de Janeiro: Editora Lumen Juris. p. 153-191. Disponível em <http://www.bmalaw.com.br/arquivos/Artigos/11-09 NOTAS_SOBRE_A_ADMINISTRACAO_DAS_SOCIEDADES_LIMITADAS. PDF>. Acesso em 01 nov. 2016.

PRADO, Roberta Nioac; DONAGGIO Angela Rita Franco. Responsabilidade pessoal dos administradores e sócios por atos praticados em nome da sociedade e desconsideração da personalidade jurídica. Revista Direito GV, v.3 n. 1. P.075-100, Jan-Jun 2007. Disponível em < http://bdjur.stj.jus.br/jspui/bitstream/2011/102560/responsabilidade_pessoal_adm inistradores_donaggio.pdf>. Acesso em 15 nov. 2016

TEIXEIRA Egberto Lacerda, Sociedades limitadas e anônimas no direito brasileiro: estudo comparativo. São Paulo: Saraiva, 1987

TOLEDO, Paulo Fernando Campos Salles de. O conselho de administração na sociedade anônima: estrutura, funções e poderes, responsabilidade dos administradores. São Paulo: Atlas, 1997

VERÇOSA, Haroldo Malheiros Duclerc. Direito Comercial. v.3. 3. ed rev., atual e ampl. São Paulo: Editora Revista dos Tribunais, 2014. p. 422

ZANETTI, Robson. Manual da sociedade limitada. Curitiba: Juruá, 2007. 432p. 